Check for updates

Cite this: RSC Adv., 2017, 7, 26401

Received 6th April 2017

Accepted 9th May 2017

DOI: 10.1039/c7ra03915h

rsc.li/rsc-advances

\title{
Design, synthesis and evaluation of novel angiotensin II receptor 1 antagonists with antihypertensive activities $\uparrow$
}

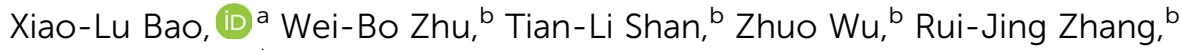 \\ Ping-Yong Liao, ${ }^{b}$ Mei-Zhen Zheng, ${ }^{c}$ He-Sheng Tang, ${ }^{c}$ Yi-Jia Yan ${ }^{* c}$ \\ and Zhi-Long Chen*ab
}

\begin{abstract}
A series of novel angiotensin II receptor 1 antagonists (1a-f, 2a-f) were designed, synthesized and evaluated. Radioligand binding assays showed that all these prepared compounds displayed nanomolar affinity for angiotensin II type 1 receptor, among which compound $1 \mathrm{f}$ was more affinitive than telmisartan at the same order of magnitude with an $\mathrm{IC}_{50}$ value of $1.13 \pm 1.68 \mathrm{nM}$. The antihypertensive effects showed that all these compounds could decrease blood pressure in a dose dependent manner on spontaneously hypertensive rats. And compound 2-(4-((2-butyl-4-methyl-6-(oxazolo[4,5-b]pyridine2-yl)benzimidazole-1-yl)methyl)-1H-indol-1-yl) benzoic acid (1f), showed efficient and long-lasting effects in reducing blood pressure, with a maximal response lowered $55.98 \pm 4.74 \mathrm{mmHg}$ at $10 \mathrm{mg} \mathrm{kg}^{-1}$ and $35.82 \pm 6.20 \mathrm{mmHg}$ at $5 \mathrm{mg} \mathrm{kg}^{-1}$, the antihypertensive effect of it lasted beyond $24 \mathrm{~h}$ which was better than telmisartan. In the single-dose pharmacokinetic experiments, compound if was absorbed efficiently and metabolized smoothly in Wistar rats. The values of $C_{\max }, T_{\max }, \mathrm{AUC}_{0-72}, \mathrm{MRT}_{0-72}$ and $T_{1 / 2}$ were $17.92 \pm 10.85 \mathrm{ng} \mathrm{mL}^{-1}, 2.60 \pm 3.05 \mathrm{~h}, 252.85 \pm 144.59 \mathrm{ng} \mathrm{mL}^{-1} \mathrm{~h}, 18.75 \pm 0.43 \mathrm{~h}$ and $17.16 \pm$ $4.24 \mathrm{~h}$ respectively. Compound $1 \mathrm{f}$ was distributed into tissues rapidly and extensively after oral administration and the level of it was the highest in the liver, followed by in the kidney, and the lowest in brain. The acute toxicity assays in ICR rats of $1 \mathrm{f}$ showed that it had low acute toxicity with an LD $_{50}$ value of $1459.89 \mathrm{mg} \mathrm{kg}^{-1}$. These encouraging results make $1 \mathrm{f}$ an efficient, long-acting and safe antihypertensive drug candidate and deserving of further investigation.
\end{abstract}

\section{Introduction}

Hypertension is a growing undesired symptom and usually associated with many complications, such as coronary heart disease, stroke, myocardial infarction and renal disease. The renin-angiotensin aldosterone system (RAAS) plays a critical role in blood pressure regulation and electrolyte/fluid homeostasis. ${ }^{1}$ The octapeptide angiotensin II is the main pressor component of the RAAS and angiotensin II (Ang II) receptor antagonists are widely accepted as novel antihypertensive drugs because of the small side effects and good therapeutic profiles. ${ }^{2}$ The first nonpeptidic Ang II receptor antagonists, $N$-benzylimidazole-5-acetic acid derivatives, were firstly reported by the Takeda laboratories.

${ }^{a}$ State Key Laboratory for Modification of Chemical Fibers and Polymer Materials, College of Materials Science and Engineering, Donghua University, 2999 North Renmin Road, Shanghai 201620, P. R. China. E-mail: zlchen1967@qq.com

${ }^{b}$ Department of Pharmaceutical Science and Technology, College of Chemistry and Biology, Donghua University, Shanghai 201600, China

'Shanghai Xianhui Pharmaceutical Co., Ltd, 2399 Guangfulin Road, Shanghai 200433, China.E-mail: shxh2006@outlook.com

$\dagger$ Electronic supplementary information (ESI) available. See DOI: $10.1039 / \mathrm{c} 7 \mathrm{ra03915h}$
Since then, this imidazole lead has been developed into a series of potent, selective and orally active $\mathrm{AT}_{1}$ receptor antagonists. Losartan (Fig. 1) is the most widely used drug of this series, and numerous modifications to its chemical structure have generated a large number of Ang II antagonists including valsartan, irbesartan, telmisartan, candesartan, olmesartan and so on., All these drugs contain common structural features represented by

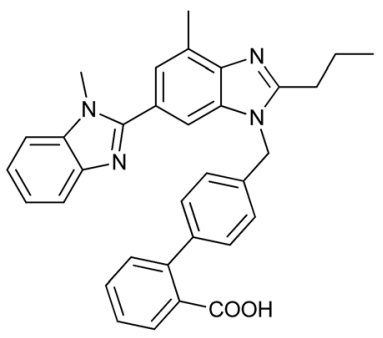

Telmisartan
BBIB

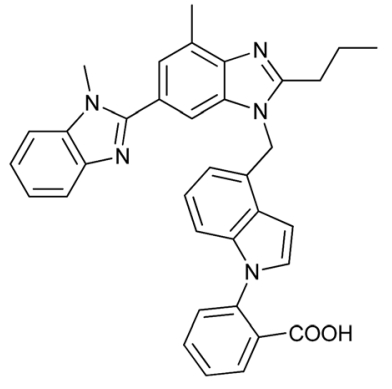

Fig. 1 Non-peptide angiotensin II receptor antagonists telmisartan and BBIB. 

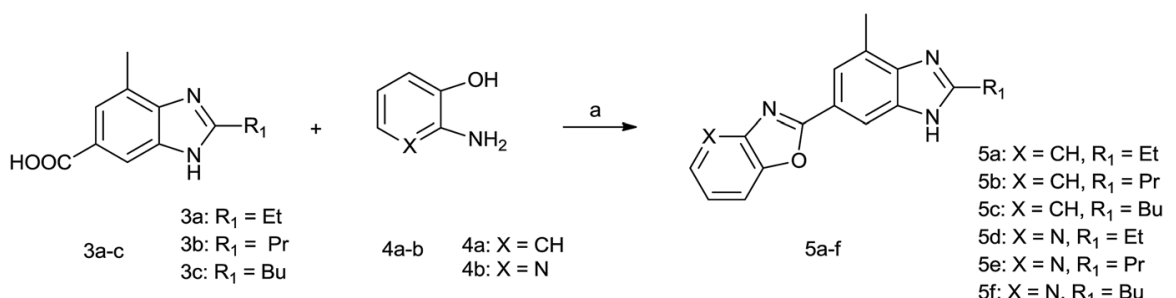

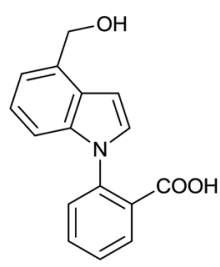

$6 a$

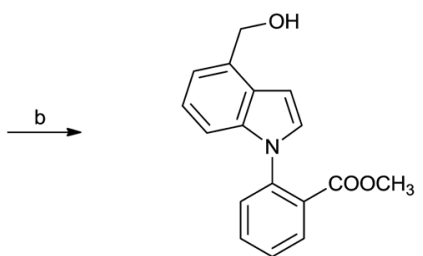

$7 a$<smiles></smiles>

1a-f

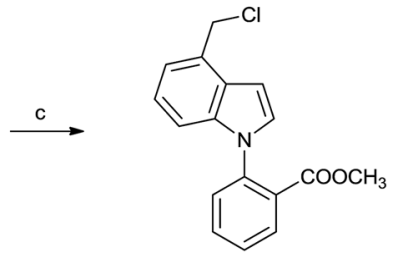

$8 a$

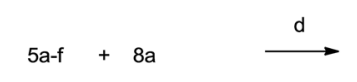

Scheme 1 Reagents and reaction conditions: (a) PPA, $150{ }^{\circ} \mathrm{C}, 12 \mathrm{~h}, 40-51 \%$; (b) $\mathrm{CH}_{3}$ l, $\mathrm{KHCO}_{3}, \mathrm{DMF}, 5 \mathrm{~h}, 95 \%$; (c) $\mathrm{HCl}-\mathrm{EtOH}, \mathrm{DCM}, 2 \mathrm{~h}, 82 \%$; (d) $\mathrm{NaH}, \mathrm{DMF}, 2 \mathrm{~h}$ and then $\mathrm{NaOH}, \mathrm{H}_{2} \mathrm{O}, 4$ h, 50-60\%.

a biphenyl fragment bearing an acidic moiety (i.e., tetrazole, carboxylic group) that is linked to heterocycles by means of a methylene group. ${ }^{5}$ Telmisartan (Fig. 1) is the most recently marketed drug as an $\mathrm{AT}_{1}$ receptor antagonist. Besides, indole derivatives have been extensively studied as a pharmacophore group because of their wide potential bioactivities. ${ }^{6-9}$

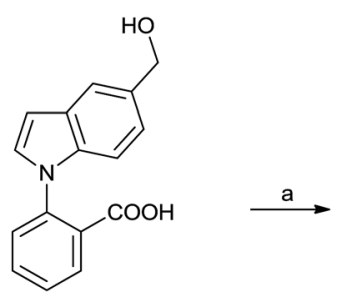

$6 \mathrm{~b}$<smiles>CC(=O)c1ccccc1-n1ccc2cc(CO)ccc21</smiles>

$7 b$<smiles>COC(=O)c1ccccc1-n1ccc2cc(CCl)ccc21</smiles>

$8 b$

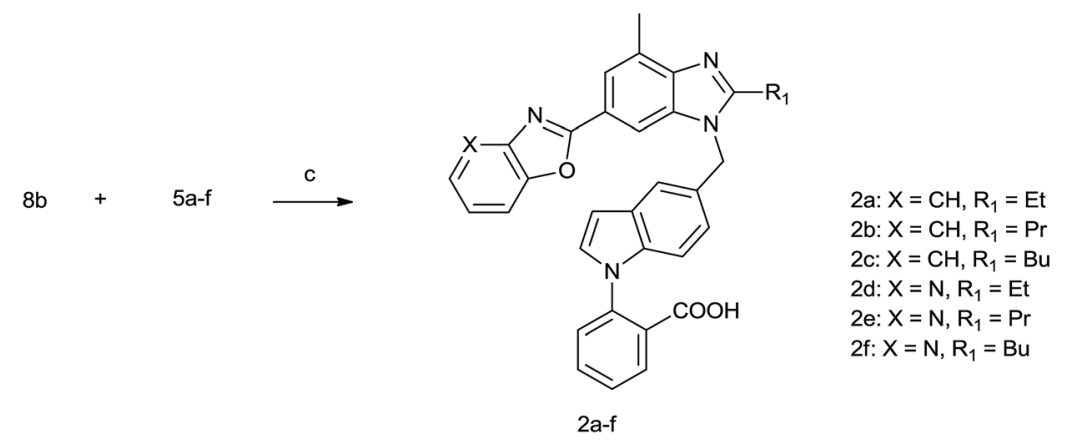

Scheme 2 Reagents and reaction conditions: (a) $\mathrm{CH}_{3} \mathrm{l}, \mathrm{KHCO}_{3}, \mathrm{DMF}, 5 \mathrm{~h}, 81 \%$; (b) $\mathrm{HCl}-\mathrm{EtOH}, \mathrm{DCM}, 2 \mathrm{~h}, 82 \%$; (c) $\mathrm{NaH}, \mathrm{DMF}, 2 \mathrm{~h}$ and then NaOH, $\mathrm{H}_{2} \mathrm{O}, 40-49 \%$. 
Table $1 \quad \mathrm{CC}_{50}$ and $K_{i}$ value of the tested compounds $1 \mathrm{a}-\mathrm{f}, 2 \mathrm{a}-\mathrm{f}$ and telmisartan

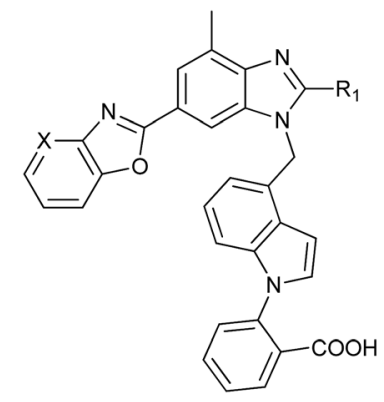

$1 a-f$

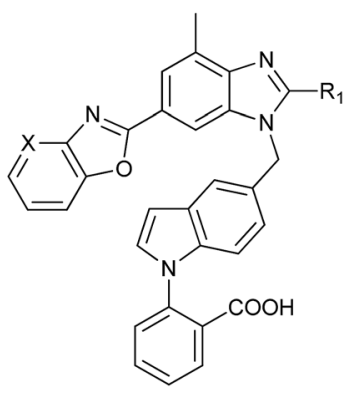

2a-f

\begin{tabular}{lllrr}
\hline Compounds & $\mathrm{X}$ & $\mathrm{R}_{1}$ & $\mathrm{IC}_{50} \pm \mathrm{SEM}(\mathrm{nM})$ & $K_{i} \pm \mathrm{SEM}(\mathrm{nM})$ \\
\hline 1a & $\mathrm{CH}$ & $\mathrm{Et}$ & $5.61 \pm 6.45$ & $4.06 \pm 4.60$ \\
1b & $\mathrm{CH}$ & $\mathrm{Pr}$ & $5.86 \pm 7.49$ & $4.04 \pm 5.43$ \\
1c & $\mathrm{CH}$ & $\mathrm{Bu}$ & $6.08 \pm 5.50$ & $4.40 \pm 3.99$ \\
1d & $\mathrm{N}$ & $\mathrm{Et}$ & $14.25 \pm 6.34$ & $10.32 \pm 4.60$ \\
1e & $\mathrm{N}$ & $\mathrm{Pr}$ & $4.37 \pm 1.63$ & $3.17 \pm 1.18$ \\
1f & $\mathrm{N}$ & $\mathrm{Bu}$ & $1.13 \pm 1.68$ & $0.82 \pm 0.12$ \\
2a & $\mathrm{CH}$ & $\mathrm{Et}$ & $5.77 \pm 1.65$ & $4.18 \pm 1.20$ \\
2b & $\mathrm{CH}$ & $\mathrm{Pr}$ & $9.07 \pm 4.67$ & $6.57 \pm 3.38$ \\
2c & $\mathrm{CH}$ & $\mathrm{Bu}$ & $6.40 \pm 6.67$ & $4.63 \pm 4.83$ \\
2d & $\mathrm{N}$ & $\mathrm{Et}$ & $10.24 \pm 5.27$ & $7.42 \pm 3.82$ \\
2e & $\mathrm{N}$ & $\mathrm{Pr}$ & $5.20 \pm 6.70$ & $3.77 \pm 4.85$ \\
2f & $\mathrm{N}$ & $\mathrm{Bu}$ & $12.63 \pm 6.52$ & $9.15 \pm 5.23$ \\
Telmisartan & & & $2.12 \pm 0.14$ & $1.53 \pm 0.10$ \\
& & &
\end{tabular}

In our previous work, a potential new compound 2-[4-[[2- $n-$ propyl-4-methyl-6-(1-methylbenzimidazol-2-yl)benzimidazole-1yl]methyl]-1H-indol-1-yl]benzoicacid (BBIB, Fig. 1) was found reducing blood pressure more effectively than losartan and telmisartan. ${ }^{10}$ Based on the analysis of the chemical structure of telmisartan and BBIB, herein, a series of novel potent non-peptide $\mathrm{AT}_{1}$ receptor antagonists were designed and synthesized. Their pharmacological activities were evaluated, including the affinity to

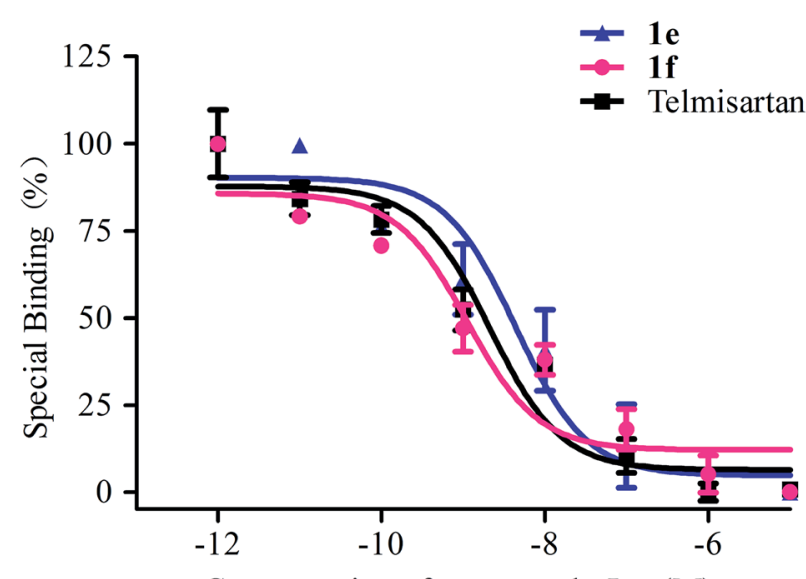

Concentration of compounds, $\log (\mathrm{M})$

Fig. 2 Inhibitory effects of new compounds 1e, 1f and telmisartan $\left(10^{-5}\right.$ to $\left.10^{-11} \mathrm{M}\right)$ on the specific binding of ${ }^{125}$-Ang II to $A T_{1}$ receptors in VSMCs.
$\mathrm{AT}_{1}$ receptor in vitro and antihypertensive effect in vivo. The plasma pharmacokinetics, tissue distribution in Wistar rats and acute toxicity in ICRs of the most potential compound were further investigated.
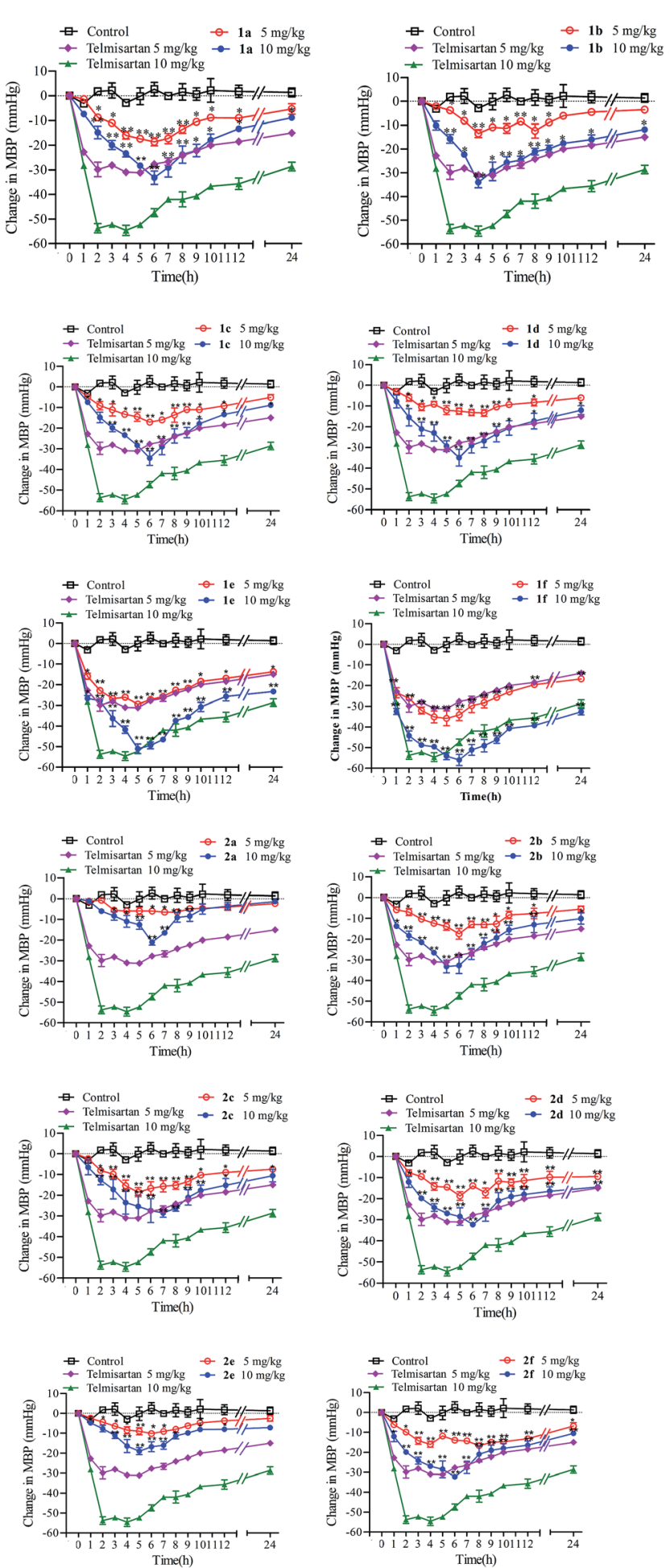

Fig. 3 The anti-hypertensive effect of new compounds (1a-f, $2 a-f)$ and losartan in spontaneously hypertensive rats at $5 \mathrm{mg} \mathrm{kg}^{-1}$ and $10 \mathrm{mg} \mathrm{kg}^{-1}$. Data were average values of 6 experiments (mean $\pm \mathrm{SD}$ ). *, **Significant difference from the control, $p<0.05$ and $p<0.01$, respectively. 


\section{Results and discussion}

\section{Chemistry}

We developed a general and useful synthesis of indole derivatives 1a-f, 2a-f with a variety of substituents. In short, this procedure comprised of two coupling parts, one gave the chlorine and the other gave the heterocyclic amine. We initially synthesized the halide component which was coupled to the heterocyclic fragment to construct the target molecule. And the preparation of new compounds was performed by means of a multistep procedure described in Scheme 1 and 2 .

The synthesis of 8a, 5a-f and 1a-f were outlined in Scheme 1. 4-Chlorinemtehyl- $N$-phenyl indole compound (8a) was obtained by chlorinating the ester of ethyl benzoate compound (7a) which was achieved through esterification of benzoic acid compound (6a). 6-Substituted benzimidazole compounds (5a-f) were obtained by the condensation reaction of 6-benzimidazole carboxylic acid compounds (3a-c) with different ortho amino phenol compounds $(\mathbf{4 a}-\mathbf{b})$. They were reacted with $\mathbf{8 a}$ to get the designed carboxylic acid compounds (1a-f).

The synthesis of 5-chlorinemethyl- $N$-phenyl indole compound (8b) was similar to that of $\mathbf{8 a}$ which was outlined in Scheme 2 . Compound $\mathbf{8 b}$ reacted with $\mathbf{5 a}-\mathbf{f}$ to get the designed carboxylic acid compounds (2a-f).

\section{Biological evaluation}

Affinities to Ang II ( $\left.\mathbf{A T}_{\mathbf{1}}\right)$ receptor in vitro. The affinity of the prepared compounds and losartan for the $\mathrm{AT}_{1}$ receptor was determined using vascular smooth muscle cells in a competition radioligand binding assay with $\left[{ }^{125} \mathrm{I}\right]$-Ang II and expressed as $\mathrm{IC}_{50}$ values. The results showed that all the prepared compounds displayed nanomolar affinity to angiotensin II type 1 receptor subtype (Table 1, Fig. 2). Generally, compounds 1e and 1f had much stronger inhibitory ability than other compounds especially $\mathbf{1 f}$ which was showed higher receptor affinity than telmisartan $\left(\mathrm{IC}_{50}=2.12 \pm 0.14 \mathrm{nM}, K_{i}=1.53 \pm\right.$ $0.10 \mathrm{nM}$ ) with the $\mathrm{IC}_{50}$ and $K_{i}$ value of $1.13 \pm 1.68 \mathrm{nM}$ and $0.82 \pm$ $0.12 \mathrm{nM}$ respectively.

Anti-hypertensive activities in vivo. The effects of prepared compounds and telmisartan on mean blood pressure (MBP) of spontaneously hypertensive rats (SHRs) in vivo at $5 \mathrm{mg} \mathrm{kg}^{-1}$ and $10 \mathrm{mg} \mathrm{kg}^{-1}$ after oral administration were shown in Fig. 3. It was observed that all the compounds could cause significant decrease of blood pressure at $5 \mathrm{mg} \mathrm{kg} \mathrm{kg}^{-1}$ and $10 \mathrm{mg} \mathrm{kg} \mathrm{kg}^{-1}$ compared with blank control group, among them, compound 1e and 1f displayed higher anti-hypertensive effect than other compounds especially 1f. The maximal response of $\mathbf{1 f}$ lowered $55.98 \pm 4.74 \mathrm{mmHg}$ of MBP at $10 \mathrm{mg} \mathrm{kg}^{-1}$ and $35.82 \pm 6.20$

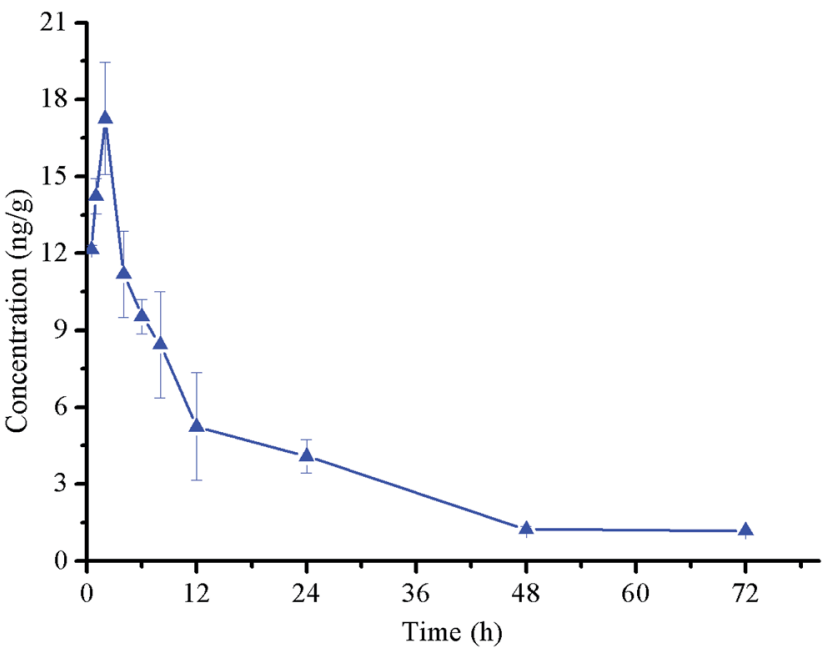

Fig. 4 Observed plasma concentrations of $1 \mathrm{f}$ in rats after signal oral administration at $10 \mathrm{mg} \mathrm{kg}^{-1}$. Data were average values of 8 experiments (mean $\pm \mathrm{SD}$ ).

mmHg at $5 \mathrm{mg} \mathrm{kg}^{-1}$ which was better than telmisartan. The significant antihypertensive effect of it lasted beyond $24 \mathrm{~h}$.

Pharmacokinetic characteristics of compound 1f. The concentrations of compound $\mathbf{1 f}$ in rat plasma obtained from 8 male Wistar rats were quantified. The pharmacokinetic parameters were shown in Table 2 and the mean peak plasma concentration-time curve was shown in Fig. 4. The maximum concentration $\left(C_{\max }\right)$ value was $17.92 \pm 10.85 \mathrm{ng} \mathrm{mL}^{-1}$, the area under the concentration-time curve from 0 to $72 \mathrm{~h}\left(\mathrm{AUC}_{0-72}\right)$ was $252.85 \pm 144.59 \mathrm{ng} \mathrm{mL}{ }^{-1} \mathrm{~h}$, the elimination half-lives $\left(T_{1 / 2}\right)$ was $17.16 \pm 4.24 \mathrm{~h}$ and the time reach to maximum concentration was $2 \mathrm{~h}$.

The compound levels in heart, liver, spleen, kidney and brain of Wistar rats at $0.5,1,2,4,6,8,12,24,48,72 \mathrm{~h}$ post oral administration of compound $\mathbf{1 f}$ at $10 \mathrm{mg} \mathrm{kg}^{-1}$ were shown in Fig. 5 and the pharmacokinetic parameters were shown in Table 3. It was found that $\mathbf{1 f}$ was distributed extensively in rat tissues. And it was accumulated especially in liver which exhibited the highest concentration of $152.87 \pm 10.10 \mathrm{ng} \mathrm{g}^{-1}$ followed by kidney of $5.84 \pm 2.14 \mathrm{ng} \mathrm{g}^{-1}$ and the lowest in brain of $1.31 \pm 0.59 \mathrm{ng} \mathrm{g}^{-1}$. These results indicate that liver and renal transporters might play an important role in the disposition of 1f. Since the highest concentration of telmisartan after oral administration was also detected in liver and followed by in kidney, ${ }^{11}$ the distribution of $\mathbf{1 f}$ appeared to have some similarity to telmisartan. Information on the likelihood of crossing the blood brain barrier (BBB) is important for targets related to central nervous system (CNS). 1f was detectable in brain which

Table 2 Pharmacokinetic parameters of compound $1 \mathrm{f}$ in plasma of male Wistar rats after oral administration at $10 \mathrm{mg} \mathrm{kg}^{-1}$. Data were average values of 8 experiments (mean \pm SD)

\begin{tabular}{|c|c|c|c|c|c|c|}
\hline$C_{\max }\left(\mathrm{ng} \mathrm{mL}^{-1}\right)$ & $T_{\max }(\mathrm{h})$ & $T_{1 / 2}(\mathrm{~h})$ & $\operatorname{AUC}_{(0-72)}\left(\mathrm{ng} \mathrm{mL}^{-1} \mathrm{~h}\right)$ & $\operatorname{AUC}_{(0-\infty)}\left(\mathrm{ng} \mathrm{mL}^{-1} \mathrm{~h}\right)$ & $\mathrm{MRT}_{(0-72)}(\mathrm{h})$ & $\operatorname{MRT}_{(0-\infty)}(\mathrm{h})$ \\
\hline $17.92 \pm 10.85$ & $2.60 \pm 3.05$ & $17.16 \pm 4.24$ & $252.85 \pm 144.59$ & $268.28 \pm 155.94$ & $18.75 \pm 0.43$ & $29.66 \pm 5.21$ \\
\hline
\end{tabular}


a

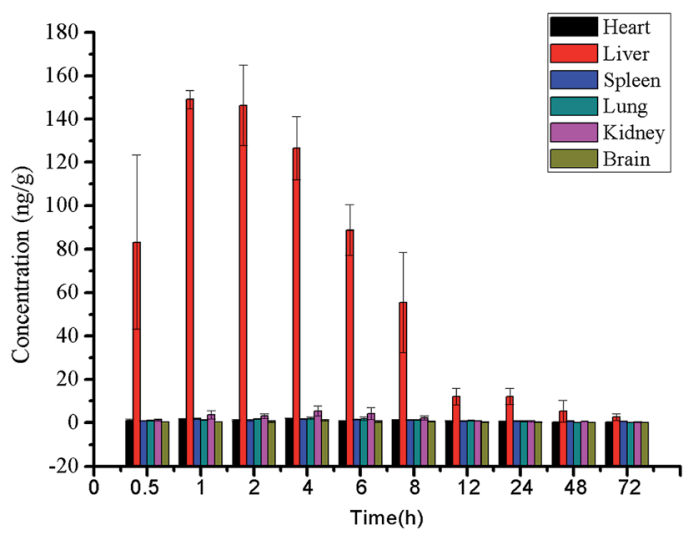

$\mathrm{b}$

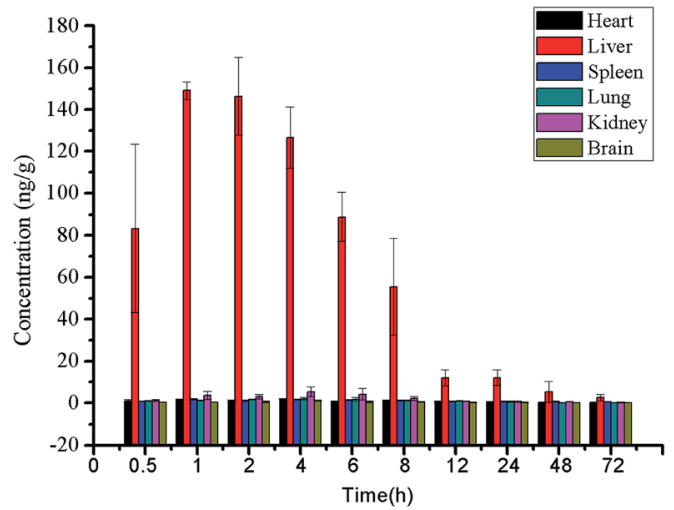

Fig. 5 Observed tissues concentrations of $1 \mathrm{f}$ in Wistar rats after signal oral administration at $10 \mathrm{mg} \mathrm{kg}$. (a) Concentration of $1 \mathrm{f}$ in tissues including liver; (b) concentration of $1 \mathrm{f}$ in tissues didn't including liver. Data were average values of 6 experiments (mean $\pm S D$ ).

Table 3 Pharmacokinetic parameters of compound $1 \mathrm{f}$ in tissues of Wistar rats after oral administration at $10 \mathrm{mg} \mathrm{kg}{ }^{-1}$. Data were average values of 6 experiments (mean \pm SD)

\begin{tabular}{lcccccc}
\hline Tissue & $C_{\max }\left(\mathrm{ng} \mathrm{g}^{-1}\right)$ & $T_{\max }(\mathrm{h})$ & $T_{1 / 2}(\mathrm{~h})$ & $\mathrm{AUC}_{(0-72)}\left(\mathrm{ng} \mathrm{g}^{-1} \mathrm{~h}\right)$ & $\mathrm{AUC}_{(0-\infty)}\left(\mathrm{ng} \mathrm{g}^{-1} \mathrm{~h}\right)$ & $\mathrm{AUC}_{\text {tissue }} / \mathrm{AUC}_{\text {plasma }}$ \\
\hline Heart & $2.26 \pm 0.16$ & $3.25 \pm 1.50$ & $16.87 \pm 7.91$ & $31.16 \pm 8.34$ & $33.51 \pm 6.37$ & 0.12 \\
Liver & $152.87 \pm 10.10$ & $1.33 \pm 0.58$ & $22.81 \pm 3.60$ & $1444.65 \pm 273.97$ & $1541.40 \pm 241.08$ & 5.71 \\
Spleen & $1.92 \pm 0.23$ & $2.00 \pm 1.73$ & $23.12 \pm 1.23$ & $25.70 \pm 7.38$ & $29.68 \pm 8.33$ & 0.10 \\
Lung & $2.12 \pm 0.61$ & $4.00 \pm 2.00$ & $13.02 \pm 3.59$ & $37.14 \pm 8.74$ & $38.05 \pm 8.43$ & 0.15 \\
Kidney & $5.84 \pm 2.14$ & $3.00 \pm 1.73$ & $19.15 \pm 3.12$ & $66.78 \pm 21.53$ & $71.61 \pm 21.07$ & 0.26 \\
Brain & $1.31 \pm 0.59$ & $3.33 \pm 1.16$ & $17.83 \pm 1.35$ & $15.47 \pm 7.94$ & $16.40 \pm 8.87$ & 0.06
\end{tabular}

means it could penetrate the BBB. Telmisartan was also able to cross the BBB after oral administration, but other sartans such as candesartan, losartan, and valsartan were poorly penetrated to BBB. ${ }^{12}$ Thus, $1 f$ may have effect on dilating cerebral blood vessels, improving cerebral circulation and hence could be useful for the potential treatment of ischemic cerebrovascular disease. ${ }^{13,14}$

These results also showed that compound 1f was absorbed and distributed efficiently and metabolized gradually in plasma and in tissues of Wistar rats.

Acute toxicity test. The acute toxicity assay showed that compound $\mathbf{1 f}$ had low acute toxicity with the $\mathrm{LD}_{50}$ value of $1459.89 \mathrm{mg} \mathrm{kg}^{-1}$ and the $95 \%$ confidence interval was $1246.98-$

Table 4 The lethal dose $\left(L_{50}\right)$ of compound $1 \mathrm{f}$ determined by acute toxicity test

\begin{tabular}{llll}
\hline $\begin{array}{l}\text { Dose } \\
\left(\mathrm{mg} \mathrm{kg}^{-1}\right)\end{array}$ & $\log ($ dose $)$ & $\begin{array}{l}\text { Mortality } \\
(\%)\end{array}$ & $\begin{array}{l}\mathrm{LD}_{50}\left(\mathrm{mg} \mathrm{kg}^{-1}\right) \text { and } 95 \% \\
\text { confidence interval }\left(\mathrm{mg} \mathrm{kg}^{-1}\right)\end{array}$ \\
\hline 632.81 & 2.80 & 0 & $1459.89(1246.98-1717.49)$ \\
843.75 & 2.93 & 10 & \\
1125.00 & 3.05 & 20 & \\
1500.00 & 3.18 & 40 & \\
2000.00 & 3.30 & 90 & \\
2666.67 & 3.43 & 100 &
\end{tabular}

$1717.49 \mathrm{mg} \mathrm{kg}^{-1}$ (Table 4). There was no physiological abnormality detected within mice after administered with dose of $632.81 \mathrm{mg} \mathrm{kg}^{-1}$ and no significant differences in weight and visible tissue lesions of survivals in two weeks' observation. As telmisartan was well tolerated at $2000 \mathrm{mg} \mathrm{kg}^{-1}$ after oral administration, 1f showed higher acute toxicity than telmisartan. However, 1f showed superior antihypertensive activity than telmisartan (as it could reduce about $36 \mathrm{mmHg}$ of $\mathrm{MBP}$ at $5 \mathrm{mg} \mathrm{kg}{ }^{-1}$ ) and hence may possess acceptable safety window.

\section{Conclusions}

A series of novel 6-substituted benzimidazole with 1,4-disubstituted or 1,5-disubstituted indole derivatives were designed, synthesized and evaluated. The Ang II antagonistic activities in vitro and antihypertensive activities in vivo of them were investigated to assess their antihypertensive effect. All the prepared compounds displayed nanomolar affinity for angiotensin II type 1 receptor and could course obvious reduction in blood pressure. Among these compounds, 1 f showed more affinitive to $\mathrm{AT}_{\mathbf{1}}$ receptor with an $\mathrm{IC}_{50}$ value of $1.13 \pm 1.68 \mathrm{nM}$ respectively than telmisartan $\left(\mathrm{IC}_{50}=2.12 \pm 0.14 \mathrm{nM}\right)$. Also, 1f had significant antihypertensive effects in SHRs with the maximal response of $55.98 \pm 4.74 \mathrm{mmHg}$ at $10 \mathrm{mg} \mathrm{kg}^{-1}$ and $35.82 \pm 6.20 \mathrm{mmHg}$ at $5 \mathrm{mg} \mathrm{kg}{ }^{-1}$, the significant antihypertensive effect of it lasted beyond $24 \mathrm{~h}$ which was better than telmisartan. The 
pharmacokinetic experiments showed that 1 f could be absorbed efficiently and metabolized smoothly in Wistar rats after oral administration. With single-dose $1 \mathrm{f}$ at $10 \mathrm{mg} \mathrm{kg}^{-1}$, the $C_{\text {max }}, T_{\text {max }}, \mathrm{AUC}_{0-72}$, and $T_{1 / 2}$ value were $17.92 \pm 10.85 \mathrm{ng} \mathrm{mL}^{-1}$, $2.60 \pm 3.05 \mathrm{~h}, 252.85 \pm 144.59 \mathrm{ng} \mathrm{mL}^{-1} \mathrm{~h}$ and $17.16 \pm 4.24 \mathrm{~h}$ respectively. It was well distributed in tissues including in brain which suggested that 1f could cross the blood-brain barrier (BBB) and might play important role in the control of central nervous system blood pressure. The acute toxicity assay of $\mathbf{1 f}$ showed that it had low acute toxicity with no significant changes in the weight and no obvious untoward reactions. The $\mathrm{LD}_{50}$ value of it was $1459.89 \mathrm{mg} \mathrm{kg}{ }^{-1}$. These encouraging results make 1f an effective and durable anti-hypertension drug candidate deserving for further investigation.

\section{Material and methods}

\section{Chemistry}

All chemical reagents were purchased from commercial suppliers and were used without further purification. Yields of the purified products were not optimized. Melting points (MP) were measured on an electro thermal melting point apparatus and were not corrected. ${ }^{1} \mathrm{H}$ NMR spectra were measured on a Bruker $400 \mathrm{MHz}$ spectrometer using TMS $\left(\mathrm{Me}_{4} \mathrm{Si}\right)$ as internal standard. ESI-MS spectra were recorded on a Micromass triple quadrupole mass spectrometer. Column chromatography was performed using silica gel $\mathrm{H}$ (300-400 meshes).

General procedure for the synthesis of 3a-c. Methyl 4-amino3-methylbenzoate $(10.00 \mathrm{~g}, 60.58 \mathrm{mmol})$ was acylated with alkyl acyl chloride $(90.87 \mathrm{mmol})$ and triethylamine $(16.79 \mathrm{~mL}$, $121.16 \mathrm{mmol}$ ) in DCM at $0{ }^{\circ} \mathrm{C}$. The resulting amide was reacted with fuming nitric acid in sulfuric acid $(60 \%)$ at $-20{ }^{\circ} \mathrm{C}$. The resulting nitro-compound was reduced with hydrogen (5 bar) and RANEY® $\mathrm{Ni}(0.79 \mathrm{~g}, 13.34 \mathrm{mmol})$ in methanol at reflux. The resulting amino compound was dissolved in glacial acetic acid and heated under reflux for $1 \mathrm{~h}$. After evaporation of the acetic acid, water was added to the residue and the $\mathrm{pH}$ value was adjusted to 9 by addition of concentrated ammonia. This solution was extracted with ethyl acetate $(3 \times 100 \mathrm{~mL})$. The combined organic layers were washed with aqueous $\mathrm{NaHCO}_{3}$ solution and dried over $\mathrm{MgSO}_{4}$. After filtration, the solvent was removed under reduced pressure. ${ }^{\mathbf{1 0}}$

Methyl 2-ethyl-4-methyl-benzo[d]imidazole-6-carboxylate (3a). The above general procedure was followed by using propionyl chloride. The residue was purified by column chromatography to give the product as yellow oil. Yield: $50 \% .{ }^{1} \mathrm{H}$ NMR $(400 \mathrm{MHz}$, $\left.\mathrm{CDCl}_{3}\right): \delta \mathrm{ppm} 8.10(\mathrm{~s}, 1 \mathrm{H}), 7.96(\mathrm{~s}, 1 \mathrm{H}), 3.96(\mathrm{~s}, 3 \mathrm{H}), 2.70(\mathrm{~s}, 3 \mathrm{H})$, $2.63(\mathrm{~s}, 3 \mathrm{H})$. MS (ESI) $m / z: 205.1[\mathrm{M}+\mathrm{H}]^{+}$.

Methyl 2-propyl-4-methyl-1H-benzo[d]imidazole-6-carboxylate (3b). The above general procedure was followed by using butyryl chloride. The residue was purified by column chromatography to give the product as yellow oil. Yield: $52 \% .{ }^{1} \mathrm{H}$ NMR $(400 \mathrm{MHz}$, $\left.\mathrm{CDCl}_{3}\right): \delta \mathrm{ppm} 8.15(\mathrm{~s}, 1 \mathrm{H}), 7.88(\mathrm{~s}, 1 \mathrm{H}), 3.93(\mathrm{~s}, 3 \mathrm{H}), 2.81(\mathrm{q}, 2 \mathrm{H})$, $2.63(\mathrm{~s}, 3 \mathrm{H}), 1.45$ (t, 3H). MS (ESI) $m / z: 219.1[\mathrm{M}+\mathrm{H}]^{+}$.

Methyl 2-butyl-4-methyl-1H-benzo[d]imidazole-6-carboxylate (3c). The above general procedure was followed by using valeryl chloride. The residue was purified by column chromatography to give the product as yellow oil. Yield: $56 \%$. ${ }^{1} \mathrm{H}$ NMR $(400 \mathrm{MHz}$, $\left.\mathrm{CDCl}_{3}\right): \delta \mathrm{ppm} 8.15(\mathrm{~s}, 1 \mathrm{H}), 7.88(\mathrm{~s}, 1 \mathrm{H}), 3.93(\mathrm{~s}, 3 \mathrm{H}), 2.81(\mathrm{q}, 2 \mathrm{H})$, 2.63 (s, 3H), 1.45 (t, 3H). MS (ESI) $m / z: 232.1[\mathrm{M}+\mathrm{H}]^{+}$.

General procedure for the synthesis of $5 \mathrm{a}-\mathrm{f}$. Compound 3 $(2.45 \mathrm{mmol})$ was slowly added into polyphosphate $(15 \mathrm{~mL})$ at $80^{\circ} \mathrm{C}$, and reaction mixture was heated to $150^{\circ} \mathrm{C}$. Compound 4 $(2.94 \mathrm{mmol})$ was slowly added to the reaction mixture for 5 times. After adding completely, the reaction continued with stirring at $150{ }^{\circ} \mathrm{C}$ for another $12 \mathrm{~h}$. After which the mixture was poured into ice water $(100 \mathrm{~mL})$, the $\mathrm{pH}$ was adjusted to 8-10 by adding concentrate ammonium hydroxide, then the filter cake was filtrated and washed with $5 \%$ ethanol solution for 3 times. ${ }^{15}$

2-Ethyl-4-methyl-6-(benzoxazol-2-yl)benzimidazole (5a). The filter solution was concentrated in vacuo and the residue was purified by column chromatography to give brown solid compound 5a. Yield: 50\%. Mp: $190-193{ }^{\circ} \mathrm{C} .{ }^{1} \mathrm{H}$ NMR $(400 \mathrm{MHz}$, $\left.\mathrm{CDCl}_{3}\right): \delta \mathrm{ppm} 8.21(\mathrm{~s}, 1 \mathrm{H}), 7.87(\mathrm{~s}, 1 \mathrm{H}), 7.78(\mathrm{~d}, 1 \mathrm{H}), 7.48-7.42$ (m, 1H), 7.23-7.18 (m, 1H), 6.85-6.79 (m, 1H), $2.93(\mathrm{q}, 2 \mathrm{H}), 2.67$ $(\mathrm{s}, 3 \mathrm{H}), 1.38(\mathrm{t}, 3 \mathrm{H})$. MS (ESI) $m / z: 278.2[\mathrm{M}+\mathrm{H}]^{+}$.

2-Propyl-4-methyl-6-(benzoxazol-2-yl)benzimidazole (5b). The synthesis of compound $\mathbf{5 b}$ was similar to that of compound $\mathbf{5 a}$, obtaining as yellow solid. Mp: $191-193{ }^{\circ} \mathrm{C}$. Yield: $54 \% .{ }^{1} \mathrm{H}$ NMR (400 MHz, $\left.\mathrm{CDCl}_{3}\right): \delta$ ppm $8.22(\mathrm{~s}, 1 \mathrm{H}), 7.89(\mathrm{~s}, 1 \mathrm{H}), 7.78(\mathrm{~d}, 1 \mathrm{H})$, $7.48-7.45(\mathrm{~m}, 1 \mathrm{H}), 7.23-7.18(\mathrm{~m}, 1 \mathrm{H}), 6.85-6.79(\mathrm{~m}, 1 \mathrm{H}), 2.88(\mathrm{t}$, $2 \mathrm{H}), 2.67$ (s, 3H), 1.88-1.79 (m, 2H), 0.99 (t, 3H). MS (ESI) m/z: $292.2[\mathrm{M}+\mathrm{H}]^{+}$.

2-Butyl-4-methyl-6-(benzoxazol-2-yl)benzimidazole (5c). The synthesis of compound 5c was similar to that of compound $\mathbf{5 a}$, obtaining as yellow solid. Yield: $48 \%$. Mp: $192-195{ }^{\circ} \mathrm{C} .{ }^{1} \mathrm{H}$ NMR (400 MHz, $\left.\mathrm{CDCl}_{3}\right): \delta$ ppm $8.22(\mathrm{~s}, 1 \mathrm{H}), 7.89(\mathrm{~s}, 1 \mathrm{H}), 7.78(\mathrm{~d}, 1 \mathrm{H})$, 7.48-7.44 (m, 1H), 7.23-7.17 (m, 1H), 6.85-6.79 (m, 1H), 2.88 $(\mathrm{t}, 2 \mathrm{H}), 2.67(\mathrm{~s}, 3 \mathrm{H}), 1.83-1.77(\mathrm{~m}, 2 \mathrm{H}), 1.40-1.35(\mathrm{~m}, 2 \mathrm{H}), 0.90$ $(\mathrm{t}, 3 \mathrm{H})$. MS (ESI) $m / z: 306.2[\mathrm{M}+\mathrm{H}]^{+}$.

2-Ethyl-4-methyl-6-(oxazolo[4,5-b]pyridine-2-yl)benzimidazole (5d). The synthesis of compound $\mathbf{5 d}$ was similar to that of compound 5a, obtaining as yellow solid. Yield: $48 \%$. Mp: $193-195{ }^{\circ} \mathrm{C} .{ }^{1} \mathrm{H}$ NMR (400 MHz, $\left.\mathrm{CDCl}_{3}\right): \delta \mathrm{ppm} 8.82(\mathrm{~s}, 1 \mathrm{H}), 8.55(\mathrm{~d}, J=4.9 \mathrm{~Hz}, 1 \mathrm{H}), 8.03$ (s, 1H), $7.93(\mathrm{~d}, J=8.1 \mathrm{~Hz}, 1 \mathrm{H}), 7.37$ (dd, $J=7.7,5.4 \mathrm{~Hz}, 1 \mathrm{H}), 3.20$ (q, $J=7.6 \mathrm{~Hz}, 2 \mathrm{H}), 2.74(\mathrm{~s}, 3 \mathrm{H}), 1.62(\mathrm{t}, J=7.4 \mathrm{~Hz}, 3 \mathrm{H}) . \mathrm{MS}(\mathrm{ESI}) \mathrm{m} /$ $z: 279.3[\mathrm{M}+\mathrm{H}]^{+}$.

2-Propyl-4-methyl-6-(oxazolo[4,5-b]pyridine-2-yl)benzimidazole (5e). The synthesis of compound $5 \mathbf{e}$ was similar to that of compound 5a, obtaining as yellow solid. Yield: 40\%. Mp: 194$197{ }^{\circ} \mathrm{C} .{ }^{1} \mathrm{H}$ NMR $\left(400 \mathrm{MHz}, \mathrm{CDCl}_{3}\right): \delta \mathrm{ppm} 8.82(\mathrm{~s}, 1 \mathrm{H}), 8.55(\mathrm{~d}, J$ $=4.9 \mathrm{~Hz}, 1 \mathrm{H}), 8.03(\mathrm{~s}, 1 \mathrm{H}), 7.93(\mathrm{~d}, J=8.0 \mathrm{~Hz}, 1 \mathrm{H}), 7.37(\mathrm{dd}, J=$ 7.7, $5.4 \mathrm{~Hz}, 1 \mathrm{H}), 3.10(\mathrm{t}, J=7.7 \mathrm{~Hz}, 2 \mathrm{H}), 2.76(\mathrm{~s}, 3 \mathrm{H}), 2.06-1.96$ $(\mathrm{m}, 2 \mathrm{H}), 1.12(\mathrm{t}, J=7.3 \mathrm{~Hz}, 3 \mathrm{H})$. MS (ESI) $m / z: 293.3[\mathrm{M}+\mathrm{H}]^{+}$.

2-Butyl-4-methyl-6-(oxazolo[4,5-b]pyridine-2-yl)benzimidazole (5f). The synthesis of compound $\mathbf{5 f}$ was similar to that of compound 5a, obtaining as yellow solid. Yield: 51\%. Mp: $195-198{ }^{\circ} \mathrm{C} .{ }^{1} \mathrm{H}$ NMR (400 MHz, $\left.\mathrm{CDCl}_{3}\right): \delta \mathrm{ppm} 8.81(\mathrm{~s}, 1 \mathrm{H}), 8.55(\mathrm{~d}, J=4.7 \mathrm{~Hz}$, $1 \mathrm{H}), 8.03(\mathrm{~s}, 1 \mathrm{H}), 7.92(\mathrm{~d}, J=8.0 \mathrm{~Hz}, 1 \mathrm{H}), 7.37(\mathrm{dd}, J=7.7,5.4 \mathrm{~Hz}$, $1 \mathrm{H}), 3.15(\mathrm{t}, J=7.8 \mathrm{~Hz}, 2 \mathrm{H}), 2.76(\mathrm{~s}, 3 \mathrm{H}), 2.04-1.94(\mathrm{~m}, 2 \mathrm{H}), 1.64-$ $1.56(\mathrm{~m}, 2 \mathrm{H}), 1.12$ (t, $J=7.4 \mathrm{~Hz}, 3 \mathrm{H})$. MS (ESI) $m / z: 307.3[\mathrm{M}+\mathrm{H}]^{+}$.

General procedure for the synthesis of $6 \mathbf{a}-\mathbf{b}$. Compound $\mathbf{6 a}-\mathbf{b}$ was prepared following ref. 10. 
General procedure for the synthesis of $7 \mathbf{a}-\mathbf{b}$. A solution of compound $\mathbf{6 a} / \mathbf{6 b}(10 \mathrm{~g}, 37.45 \mathrm{mmol})$ and potassium bicarbonate $(3.75 \mathrm{~g}, 37.45 \mathrm{mmol})$ in DMF $(150 \mathrm{~mL})$ was stirred at room temperature. $\mathrm{CH}_{3} \mathrm{I}(5.85 \mathrm{~g}, 41.20 \mathrm{mmol})$ was dropped slowly into reaction mixture. The reaction continued with stirring at room temperature for $2 \mathrm{~h}$. The mixture was cooled, diluted with dichloromethane $(300 \mathrm{~mL})$, washed with water $(150 \mathrm{~mL} \times 3)$ and saturated brine $(150 \mathrm{~mL} \times 3)$, dried over anhydrous $\mathrm{MgSO}_{4}$ and evaporated to dryness. ${ }^{\mathbf{1 0}}$

Methyl 2-(4-(hydroxymethyl)-1H-indol-1-yl)benzoate (7a). The residue was purified by column chromatography to give the product as yellow oil. Yield: $95 \% .{ }^{1} \mathrm{H}$ NMR (400 $\mathrm{MHz}, \mathrm{CDCl}_{3}$ ): $\delta$ ppm 8.02 (dd, 1H), 7.72-7.68 (m, 1H), 7.57-7.51 (m, 2H), 7.31 $(\mathrm{d}, 1 \mathrm{H}), 7.21-7.11(\mathrm{~m}, 3 \mathrm{H}), 6.86(\mathrm{~d}, 1 \mathrm{H}), 5.77(\mathrm{~s}, 2 \mathrm{H}), 3.47(\mathrm{~s}, 3 \mathrm{H})$. MS (ESI) $m / z: 282.1[\mathrm{M}+\mathrm{H}]^{+}$.

Methyl 2-(5-(hydroxymethyl)-1H-indol-1-yl)benzoate (7b). The synthesis of compound $7 \mathbf{b}$ was similar with $7 \mathbf{a}$, obtaining as yellow oil. Yield: $81 \% .{ }^{1} \mathrm{H}$ NMR (400 MHz, $\left.\mathrm{CDCl}_{3}\right): \delta \mathrm{ppm} 7.88(\mathrm{~d}$, $1 \mathrm{H}), 7.78(\mathrm{t}, 1 \mathrm{H}), 7.72(\mathrm{~s}, 1 \mathrm{H}), 7.64(\mathrm{~d}, 1 \mathrm{H}), 7.54(\mathrm{t}, 1 \mathrm{H}), 7.45(\mathrm{~d}$, 1H), 7.36-7.29 (m, 2H), 6.79 (d, 1H), $4.82(\mathrm{~s}, 2 \mathrm{H}), 3.51$ (s, 3H). MS (ESI) $m / z: 282.1[\mathrm{M}+\mathrm{H}]^{+}$.

General procedure for the synthesis of $8 \mathbf{a}-\mathbf{b}$. The solution of compound $7 \mathbf{a} / 7 \mathbf{b}(500 \mathrm{mg}, 1.78 \mathrm{mmol})$ in anhydrous dichloromethane $(100 \mathrm{~mL})$ was stirred in ice bath and slowly added hydrogen chloride ethanol $(0.5 \mathrm{~mL}$, about $35 \%)$ solution. The solution was allowed to stir at room temperature for 1-2 h. The reaction mixture was washed with water $(50 \mathrm{~mL} \times$ $3)$, saturated brine $(50 \mathrm{~mL} \times 3)$ and dried over anhydrous $\mathrm{MgSO}_{4}$. After filtration, the solvent was removed under reduced pressure.

Methyl 2-(5-(chloromethyl)-1H-indol-1-yl)benzoate (8a). The above general procedure get brown solid or brown oil compound (8a). Yield: $82 \%$. ${ }^{1} \mathrm{H}$ NMR (400 $\left.\mathrm{MHz}, \mathrm{CDCl}_{3}\right): \delta \mathrm{ppm}$ 8.03 (dd, 1H), 7.72-7.68 (m, 1H), 7.57-7.51 (m, 2H), 7.31 (d, 1H), 7.21-7.11 (m, 3H), 6.86 (d, 1H), 4.96 (s, 2H), 3.48 (s, 3H). MS (ESI) $m / z: 302.1[\mathrm{M}+\mathrm{H}]^{+}$.

Methyl 2-(5-(chloromethyl)-1H-indol-1-yl)benzoate (8b). The synthesis of compound $\mathbf{8 b}$ was similar to that of compound $\mathbf{8 a}$, obtaining brown yellow oil product. Yield: $82 \% .{ }^{1} \mathrm{H}$ NMR $(400$ $\left.\mathrm{MHz}, \mathrm{CDCl}_{3}\right): \delta$ ppm $7.88(\mathrm{~d}, 1 \mathrm{H}), 7.78(\mathrm{t}, 1 \mathrm{H}), 7.72(\mathrm{~s}, 1 \mathrm{H}), 7.64$ $(\mathrm{d}, 1 \mathrm{H}), 7.54(\mathrm{t}, 1 \mathrm{H}), 7.45(\mathrm{~d}, 1 \mathrm{H}), 7.36-7.29(\mathrm{~m}, 2 \mathrm{H}), 6.79(\mathrm{~d}, 1 \mathrm{H})$, $4.64(\mathrm{~s}, 2 \mathrm{H}), 3.48(\mathrm{~s}, 3 \mathrm{H})$. MS (ESI) $m / z: 302.1[\mathrm{M}+\mathrm{H}]^{+}$.

General procedure for the synthesis of $1 \mathrm{a}-\mathbf{f}, 2 \mathrm{a}-\mathrm{f}$. Compound $5(1.20 \mathrm{mmol})$ was dissolved in DMF $(20 \mathrm{~mL})$, and then sodium hydride $(86.4 \mathrm{mg}, 3.6 \mathrm{mmol}$ ) was added. The solution was stirred at room temperature for $30 \mathrm{~min}$, followed by addition the solution of compound $\mathbf{8 a} / \mathbf{8 b}$ (395 $\mathrm{mg}, 1.32 \mathrm{mmol}$ ) in DMF (10 $\mathrm{mL}$ ) slowly, and the reaction mixture was continued to stirring at room temperature for about 2-4 h. Sodium hydroxide aqueous $(2 \mathrm{M}, 2 \mathrm{~mL})$ was added and stirred at room temperature for another $2-4 \mathrm{~h}$. The reaction mixture was adjusted the $\mathrm{pH}$ to 5-6 by $2 \mathrm{M}$ hydrochloric acid, then dichloromethane $(50 \mathrm{~mL})$ and water $(100 \mathrm{~mL})$ was added into the mixture, and the organic phase was collected. The aqueous phase was extracted with dichloromethane $(50 \mathrm{~mL} \times 3)$ and then combined the organic phase. The combined organic phase was washed with saturated brine $(100 \mathrm{~mL} \times 4)$, dried over anhydrous $\mathrm{MgSO}_{4}$ and filtrated. The filtrate was removed under reduced pressure.

2-(4-((2-Ethyl-4-methyl-6-(benzoxazol-2-yl)benzimidazole-1-yl) methyl)-1H-indol-1-yl)benzoic acid (1a). The above general procedure was followed by purified by column chromatography to give the product 1a as white solid. Yield: 60\%. Mp: 261$265{ }^{\circ} \mathrm{C} .{ }^{1} \mathrm{H}$ NMR (400 MHz, DMSO- $d_{6}$ ): $\delta$ ppm $12.93(\mathrm{~s}, 1 \mathrm{H}), 8.17$ (s, 1H), $7.93(\mathrm{~m}, 2 \mathrm{H}), 7.80-7.69(\mathrm{~m}, 3 \mathrm{H}), 7.64-7.48$ (m, 3H), 7.39$7.37(\mathrm{~m}, 2 \mathrm{H}), 7.04-7.00(\mathrm{~m}, 2 \mathrm{H}), 6.73(\mathrm{~d}, J=3.2 \mathrm{~Hz}, 1 \mathrm{H}), 6.33(\mathrm{~d}, J$ $=5.8 \mathrm{~Hz}, 1 \mathrm{H}), 5.95(\mathrm{~s}, 2 \mathrm{H}), 2.91(\mathrm{q}, J=7.5 \mathrm{~Hz}, 2 \mathrm{H}), 2.69(\mathrm{~s}, 3 \mathrm{H})$, $1.31(\mathrm{t}, J=7.5 \mathrm{~Hz}, 3 \mathrm{H}) .{ }^{13} \mathrm{C} \mathrm{NMR}(101 \mathrm{MHz}, \mathrm{DMSO}): \delta \mathrm{ppm}$ 167.7 , 163.9, 159.2, 150.6, 145.0, 142.2, 137.7, 137.2, 136.0, $132.9,131.1,130.6,130.6,129.5,128.9,128.9,128.5,126.5$, 125.4 , 125.2, 122.5, 121.5, 120.1, 119.8, 116.6, 111.1, 109.8, 107.9, 101.1, 45.2, 20.8, 16.9, 12.0. HRMS (ESI): $\mathrm{m} / \mathrm{z}$ calcd for $\mathrm{C}_{33} \mathrm{H}_{27} \mathrm{~N}_{4} \mathrm{O}_{3}[\mathrm{M}+\mathrm{H}]^{+}:$527.2083; found 527.2080.

2-(4-((2-Propyl-4-methyl-6-(benzoxazol-2-yl)benzimidazole-1-yl) methyl)-1H-indol-1-yl)benzoic acid (1b). The synthesis of compound $\mathbf{1 b}$ was similar to that of compound 1a, obtaining as white solid. Yield: 58\%. Mp: 262-265 ${ }^{\circ} \mathrm{C} .{ }^{1} \mathrm{H}$ NMR $(400 \mathrm{MHz}$, DMSO- $\left.d_{6}\right): \delta$ ppm 12.89 (s, 1H), $8.14(\mathrm{~s}, 1 \mathrm{H}), 7.93(\mathrm{~m}, 2 \mathrm{H}), 7.74-$ $7.70(\mathrm{~m}, 3 \mathrm{H}), 7.66-7.45(\mathrm{~m}, 3 \mathrm{H}), 7.44-7.32(\mathrm{~m}, 2 \mathrm{H}), 7.05-6.98$ $(\mathrm{m}, 2 \mathrm{H}), 6.75(\mathrm{~s}, 1 \mathrm{H}), 6.33(\mathrm{~d}, J=6.3 \mathrm{~Hz}, 1 \mathrm{H}), 5.95(\mathrm{~s}, 2 \mathrm{H}), 2.88(\mathrm{t}$, $J=7.5 \mathrm{~Hz}, 2 \mathrm{H}), 2.68(\mathrm{~s}, 3 \mathrm{H}), 1.85-1.71(\mathrm{~m}, 2 \mathrm{H}), 0.96(\mathrm{t}, J=$ $7.2 \mathrm{~Hz}, 3 \mathrm{H}) .{ }^{13} \mathrm{C}$ NMR (101 MHz, DMSO): $\delta \mathrm{ppm} \mathrm{167.7,} \mathrm{163.9,}$ 158.2, 150.6, 145.0, 142.2, 137.6, 137.2, 135.9, 132.8, 131.2, $131.0,130.6,129.5,128.9,128.8,128.4,126.5,125.4,125.2$, 122.5, 121.5, 120.1, 119.8, 116.6, 111.1, 109.8, 108.0, 101.1, 45.2, $29.3,20.9,16.9,14.3$. HRMS (ESI): $m / z$ calcd for $\mathrm{C}_{34} \mathrm{H}_{29} \mathrm{~N}_{4} \mathrm{O}_{3}[\mathrm{M}+$ $\mathrm{H}]^{+}:$541.2240; found 541.2234.

2-(4-((2-Butyl-4-methyl-6-(benzoxazol-2-yl)benzimidazole-1-yl) methyl)-1H-indol-1-yl)benzoic acid (1c). The synthesis of compound 1c was similar to that of compound 1a, obtaining as white solid. Yield: 56\%. Mp: $264-266{ }^{\circ} \mathrm{C} .{ }^{1} \mathrm{H}$ NMR $(400 \mathrm{MHz}$, DMSO- $\left.d_{6}\right): \delta$ ppm $12.90(\mathrm{~s}, 1 \mathrm{H}), 8.15(\mathrm{~s}, 1 \mathrm{H}), 7.98-7.88(\mathrm{~m}, 2 \mathrm{H})$, 7.79-7.68 (m, 3H), 7.62-7.52 (m, 3H), 7.43-7.33 (m, 2H), 7.09$6.95(\mathrm{~m}, 2 \mathrm{H}), 6.74(\mathrm{~d}, J=3.3 \mathrm{~Hz}, 1 \mathrm{H}), 6.34(\mathrm{dd}, J=5.6,2.3 \mathrm{~Hz}$, $1 \mathrm{H}), 5.95(\mathrm{~s}, 2 \mathrm{H}), 2.89(\mathrm{t}, 2 \mathrm{H}), 2.67(\mathrm{~s}, 3 \mathrm{H}), 1.76-1.68(\mathrm{~m}, 2 \mathrm{H})$, 1.41-1.31 (m, 2H), 0.85 (t, $J=7.3 \mathrm{~Hz}, 3 \mathrm{H}) .{ }^{13} \mathrm{C}$ NMR $(101 \mathrm{MHz}$, DMSO): $\delta$ ppm 167.6, 163.9, 158.3, 150.6, 145.0, 142.2, 137.8, 137.2 , 135.9, 133.2, 131.2, 130.5, 130.3, 129.5, 129.0, 129.0, $128.5,126.5$, 125.4, 125.2, 122.5, 121.5, 120.1, 119.8, 116.7, 111.1, 109.8, 108.0, 101.2, 45.2, 29.6, 27.1, 22.4, 16.9, 14.2. HRMS (ESI): $m / z$ calcd for $\mathrm{C}_{35} \mathrm{H}_{31} \mathrm{~N}_{4} \mathrm{O}_{3}[\mathrm{M}+\mathrm{H}]^{+}$: 555.2396; found 555.2392 .

2-(4-((2-Ethyl-4-methyl-6-(oxazolo[4,5-b]pyridine-2-yl)benzimidazole-1-yl)methyl)-1H-indol-1-yl)benzoic acid (1d). The synthesis of compound 1d was similar to that of compound 1a, obtaining as white solid. Yield: $61 \%$. Mp: $260-265{ }^{\circ} \mathrm{C} .{ }^{1} \mathrm{H}$ NMR $(400 \mathrm{MHz}$, DMSO- $\left.d_{6}\right): \delta$ ppm 12.97 (s, $\left.1 \mathrm{H}\right), 8.50(\mathrm{~m}, 1 \mathrm{H}), 8.24(\mathrm{~s}, 1 \mathrm{H}), 8.17$ $(\mathrm{m}, 1 \mathrm{H}), 7.97(\mathrm{~s}, 1 \mathrm{H}), 7.92(\mathrm{~m}, 1 \mathrm{H}), 7.73(\mathrm{~m}, 1 \mathrm{H}), 7.55(\mathrm{~m}, 3 \mathrm{H})$, 7.45-7.36 (m, 1H), $7.02(\mathrm{~m}, 2 \mathrm{H}), 6.72(\mathrm{~d}, J=3.3 \mathrm{~Hz}, 1 \mathrm{H}), 6.39-$ $6.29(\mathrm{~m}, 1 \mathrm{H}), 5.96(\mathrm{~s}, 2 \mathrm{H}), 2.92(\mathrm{q}, J=7.5 \mathrm{~Hz}, 2 \mathrm{H}), 2.70(\mathrm{~s}, 3 \mathrm{H})$, $1.31(\mathrm{t}, J=7.5 \mathrm{~Hz}, 3 \mathrm{H}) .{ }^{13} \mathrm{C}$ NMR (101 MHz, DMSO): $\delta \mathrm{ppm}$ $167.7,166.5,159.7,156.4,146.7,145.6$, 143.2, 137.6, 137.2, $136.1,132.9,131.1,130.6,130.6,129.7,128.9,128.8,128.5$, $126.5,122.5,121.8,120.7,119.5,119.1,116.7,109.8,108.5$, 
101.1, 45.2, 20.9, 16.9, 12.0. HRMS (ESI): $m / z$ calcd for $\mathrm{C}_{32} \mathrm{H}_{26} \mathrm{~N}_{5} \mathrm{O}_{3}[\mathrm{M}+\mathrm{H}]^{+}$: 528.2036; found 528.2031.

2-(4-((2-Propyl-4-methyl-6-(oxazolo[4,5-b]pyridine-2-yl)benzimidazole-1-yl)methyl)-1H-indol-1-yl)benzoic acid(1e). The synthesis of compound 1e was similar to that of compound 1a, obtaining as white solid. Yield: 50\%. Mp: 262-265 ${ }^{\circ} \mathrm{C} .{ }^{1} \mathrm{H}$ NMR $(400 \mathrm{MHz}$, DMSO- $\left.d_{6}\right): \delta$ ppm 12.97 (s, $\left.1 \mathrm{H}\right), 8.50(\mathrm{dd}, J=4.9,1.3 \mathrm{~Hz}, 1 \mathrm{H})$, 8.22-8.15 (m, 2H), 7.96 (s, 1H), 7.89 (m, 1H), 7.69 (m, 1H), 7.58$7.49(\mathrm{~m}, 3 \mathrm{H}), 7.41(\mathrm{~m}, 1 \mathrm{H}), 7.05-7.00(\mathrm{~m}, 2 \mathrm{H}), 6.73(\mathrm{~d}, J=3.3 \mathrm{~Hz}$, $1 \mathrm{H}), 6.32(\mathrm{~d}, J=6.5 \mathrm{~Hz}, 1 \mathrm{H}), 5.96(\mathrm{~s}, 2 \mathrm{H}), 2.89(\mathrm{t}, J=7.6 \mathrm{~Hz}, 2 \mathrm{H})$, 2.69 (s, 3H), 1.79-1.74 (m, 2H), 0.95 (t, $J=7.3 \mathrm{~Hz}, 3 \mathrm{H}) .{ }^{13} \mathrm{C}$ NMR (101 MHz, DMSO): $\delta$ ppm 167.6, 166.5, 158.6, 156.4, 146.7, $145.7,143.2$, 137.5, 137.2, 135.9, 132.5, 130.9, 130.6, 130.6, $129.6,128.9,128.8,128.4,126.5,122.4,121.8,120.7,119.5$, 119.1, 116.6, 109.9, 108.6, 101.0, 45.3, 29.3, 20.9, 16.9, 14.3. HRMS (ESI): $m / z$ calcd for $\mathrm{C}_{33} \mathrm{H}_{28} \mathrm{~N}_{5} \mathrm{O}_{3}[\mathrm{M}+\mathrm{H}]^{+}: 542.2192$; found 542.2186 .

2-(4-((2-Butyl-4-methyl-6-(oxazolo[4,5-b]pyridine-2-yl)benzimidazole-1-yl)methyl)-1H-indol-1-yl)benzoic acid (1f). The synthesis of compound 1f was similar to that of compound 1a, obtaining as white solid. Yield: $54 \%$. Mp: $264-266{ }^{\circ} \mathrm{C} .{ }^{1} \mathrm{H}$ NMR $(400 \mathrm{MHz}$, DMSO- $\left.d_{6}\right): \delta$ ppm $13.00(\mathrm{~s}, 1 \mathrm{H}), 8.50(\mathrm{~m}, 1 \mathrm{H}), 8.23(\mathrm{~s}, 1 \mathrm{H}), 8.17$ $(\mathrm{m}, 1 \mathrm{H}), 7.96(\mathrm{~s}, 1 \mathrm{H}), 7.91(\mathrm{~m}, 1 \mathrm{H}), 7.71(\mathrm{~m}, 1 \mathrm{H}), 7.63-7.47(\mathrm{~m}$, $3 \mathrm{H}), 7.46-7.37(\mathrm{~m}, 1 \mathrm{H}), 7.05-7.00(\mathrm{~m}, 2 \mathrm{H}), 6.73(\mathrm{~d}, J=3.2 \mathrm{~Hz}$, $1 \mathrm{H}), 6.35(\mathrm{~d}, J=6.7 \mathrm{~Hz}, 1 \mathrm{H}), 5.96(\mathrm{~s}, 2 \mathrm{H}), 2.90(\mathrm{t}, 2 \mathrm{H}), 2.69(\mathrm{~s}$, $3 \mathrm{H}), 1.72(\mathrm{~m}, 2 \mathrm{H}), 1.36(\mathrm{~m}, 2 \mathrm{H}), 0.85(\mathrm{t}, J=4.5 \mathrm{~Hz}, 3 \mathrm{H}) .{ }^{13} \mathrm{C} \mathrm{NMR}$ (101 MHz, DMSO): $\delta$ ppm 167.7, 166.5, 158.8, 156.4, 146.7, $145.6,143.2$, 137.5, 137.2, 135.9, 132.9, 131.0, 130.6, 130.6, $129.6,128.8,128.8,128.4,126.5$, 122.5, 121.8, 120.7, 119.4, 119.1, 116.7, 109.9, 108.6, 101.1, 45.3, 29.6, 27.1, 22.4, 16.9, 14.2. HRMS (ESI): $m / z$ calcd for $\mathrm{C}_{34} \mathrm{H}_{30} \mathrm{~N}_{5} \mathrm{O}_{3}[\mathrm{M}+\mathrm{H}]^{+}: 556.2349$; found 556.2345 .

2-(5-((2-Ethyl-4-methyl-6-(benzoxazol-2-yl)benzimidazole-1-yl) methyl)-1H-indol-1-yl)benzoic acid (2a). The synthesis of compound 2a was similar to that of compound 1a, obtaining as white solid. Yield: 46\%. Mp: 261-264 ${ }^{\circ} \mathrm{C} .{ }^{1} \mathrm{H}$ NMR $(400 \mathrm{MHz}$, DMSO- $\left.d_{6}\right): \delta$ ppm $12.84(\mathrm{~s}, 1 \mathrm{H}), 8.20(\mathrm{~s}, 1 \mathrm{H}), 7.91(\mathrm{~d}, J=5.6 \mathrm{~Hz}$, $2 \mathrm{H}), 7.78-7.73(\mathrm{~m}, 2 \mathrm{H}), 7.70(\mathrm{~d}, J=7.6 \mathrm{~Hz}, 1 \mathrm{H}), 7.58(\mathrm{~d}, J=$ $7.6 \mathrm{~Hz}, 1 \mathrm{H}), 7.49$ (d, $J=7.9 \mathrm{~Hz}, 1 \mathrm{H}), 7.43(\mathrm{~d}, J=3.2 \mathrm{~Hz}, 1 \mathrm{H})$, 7.42-7.35 (m, 2H), $7.30(\mathrm{~s}, 1 \mathrm{H}), 7.08(\mathrm{~d}, J=8.3 \mathrm{~Hz}, 1 \mathrm{H}), 6.99(\mathrm{~d}, J$ $=8.6 \mathrm{~Hz}, 1 \mathrm{H}), 6.59(\mathrm{~d}, J=3.0 \mathrm{~Hz}, 1 \mathrm{H}), 5.70(\mathrm{~s}, 2 \mathrm{H}), 2.97(\mathrm{q}, J=$ $7.4 \mathrm{~Hz}, 2 \mathrm{H}), 2.66(\mathrm{~s}, 3 \mathrm{H}), 1.35(\mathrm{t}, J=7.4 \mathrm{~Hz}, 3 \mathrm{H}) .{ }^{13} \mathrm{C} \mathrm{NMR}(101$ MHz, DMSO): $\delta$ ppm 167.1, 163.5, 158.5, 150.2, 144.6, 141.8, $137.3,136.1,135.3,132.6,130.7,130.5$, 129.0, 128.6, 128.4, $128.3,127.9,125.0,124.7,121.0,121.0,120.6,119.6,119.4$, $118.1,110.7,110.3,107.5,102.8,46.5,20.4,16.5,11.7$. HRMS (ESI): $m / z$ calcd for $\mathrm{C}_{33} \mathrm{H}_{27} \mathrm{~N}_{4} \mathrm{O}_{3}[\mathrm{M}+\mathrm{H}]^{+}:$527.2083; found 527.2078 .

2-(5-((2-Propyl-4-methyl-6-(benzoxazol-2-yl)benzimidazole-1-yl) methyl)-1H-indol-1-yl)benzoic acid (2b). The synthesis of compound $\mathbf{2 b}$ was similar to that of compound $\mathbf{1 a}$, obtaining as white solid. Yield: 46\%. Mp: 262-265 ${ }^{\circ} \mathrm{C} .{ }^{1} \mathrm{H}$ NMR $(400 \mathrm{MHz}$, DMSO- $\left.d_{6}\right): \delta$ ppm $12.91(\mathrm{~s}, 1 \mathrm{H}), 8.18(\mathrm{~s}, 1 \mathrm{H}), 7.94-7.84(\mathrm{~m}, 2 \mathrm{H})$, 7.79-7.72 (m, 2H), $7.68(\mathrm{~m}, 1 \mathrm{H}), 7.55(\mathrm{~m}, 1 \mathrm{H}), 7.47(\mathrm{~d}, J=7.8 \mathrm{~Hz}$, 1H), $7.43(\mathrm{~d}, J=3.2 \mathrm{~Hz}, 1 \mathrm{H}), 7.41-7.35(\mathrm{~m}, 2 \mathrm{H}), 7.28(\mathrm{~s}, 1 \mathrm{H}), 7.09$ $(\mathrm{d}, J=8.5 \mathrm{~Hz}, 1 \mathrm{H}), 6.98(\mathrm{~d}, J=8.6 \mathrm{~Hz}, 1 \mathrm{H}), 6.57(\mathrm{~d}, J=3.2 \mathrm{~Hz}$, $1 \mathrm{H}), 5.71(\mathrm{~s}, 2 \mathrm{H}), 2.93(\mathrm{t}, J=7.6 \mathrm{~Hz}, 2 \mathrm{H}), 2.65$ (s, 3H), 1.93-1.74 (m, 2H), 1.00 (t, $J=7.3 \mathrm{~Hz}, 3 \mathrm{H}) .{ }^{13} \mathrm{C}$ NMR (101 MHz, DMSO): $\delta$ ppm 167.8, 163.9, 157.9, 150.6, 145.1, 142.2, 137.6, 136.5, $135.6,132.8,131.0,130.9$, 129.4, 129.0, 128.7, 128.7, 128.3, $125.4,125.2$, 121.5, 121.5, 120.9, 120.0, 119.8, 118.4, 111.2, 110.8, 108.0, 103.1, 46.9, 29.3, 21.0, 16.9, 14.3. HRMS (ESI): $\mathrm{m} / \mathrm{z}$ calcd for $\mathrm{C}_{34} \mathrm{H}_{29} \mathrm{~N}_{4} \mathrm{O}_{3}[\mathrm{M}+\mathrm{H}]^{+}$: 541.2240; found 541.2239.

2-(5-((2-Butyl-4-methyl-6-(benzoxazol-2-yl)benzimidazole-1-yl) methyl)-1H-indol-1-yl)benzoic acid (2c). The synthesis of compound 2c was similar to that of compound 1a, obtaining as white solid. Yield: 47\%. Mp: $263-266{ }^{\circ} \mathrm{C} .{ }^{1} \mathrm{H}$ NMR $(400 \mathrm{MHz}$, DMSO- $\left.d_{6}\right): \delta$ ppm 12.97 (s, 1H), $8.18(\mathrm{~s}, 1 \mathrm{H}), 7.90(\mathrm{~s}, 1 \mathrm{H}), 7.86(\mathrm{~d}$, $J=7.6 \mathrm{~Hz}, 1 \mathrm{H}), 7.80-7.71(\mathrm{~m}, 2 \mathrm{H}), 7.66(\mathrm{~m}, 1 \mathrm{H}), 7.53(\mathrm{~m}, 1 \mathrm{H})$, $7.44(\mathrm{~m}, 2 \mathrm{H}), 7.42-7.33(\mathrm{~m}, 2 \mathrm{H}), 7.28(\mathrm{~s}, 1 \mathrm{H}), 7.10(\mathrm{~d}, J=8.5 \mathrm{~Hz}$, $1 \mathrm{H}), 6.97(\mathrm{~d}, J=8.6 \mathrm{~Hz}, 1 \mathrm{H}), 6.56(\mathrm{~d}, J=3.2 \mathrm{~Hz}, 1 \mathrm{H}), 5.70(\mathrm{~s}, 2 \mathrm{H})$, $2.94(\mathrm{t}, 2 \mathrm{H}), 2.65(\mathrm{~s}, 3 \mathrm{H}), 1.82-1.68(\mathrm{~m}, 2 \mathrm{H}), 1.44-1.37(\mathrm{~m}, 2 \mathrm{H})$, $0.89(\mathrm{t}, J=7.4 \mathrm{~Hz}, 3 \mathrm{H}) .{ }^{13} \mathrm{C}$ NMR (101 MHz, DMSO): $\delta \mathrm{ppm}$ $167.8,163.9$, 158.1, 150.7, 145.1, 142.2, 137.5, 136.5, 135.7, $132.5,131.0,130.9$, 129.4, 129.0, 128.7, 128.6, 128.2, 125.4, 125.2 , 121.5, 121.4, 120.9, 120.0, 119.8, 118.4, 111.2, 110.8, 108.0, 103.1, 47.0, 29.7, 27.1, 22.4, 16.9, 14.2. HRMS (ESI): $m / z$ calcd for $\mathrm{C}_{35} \mathrm{H}_{31} \mathrm{~N}_{4} \mathrm{O}_{3}[\mathrm{M}+\mathrm{H}]^{+}$: 555.2396; found 555.2396.

2-(5-((2-Ethyl-4-methyl-6-(oxazolo[4,5-b]pyridine-2-yl)benzimidazole-1-yl)methyl)-1H-indol-1-yl)benzoic acid (2d). The synthesis of compound $\mathbf{2 d}$ was similar to that of compound 1a, obtaining as white solid. Yield: 44\%. Mp: $261-264{ }^{\circ} \mathrm{C} .{ }^{1} \mathrm{H}$ NMR $(400 \mathrm{MHz}$, DMSO- $\left.d_{6}\right): \delta$ ppm $12.82(\mathrm{~s}, 1 \mathrm{H}), 8.51(\mathrm{~d}, J=4.8 \mathrm{~Hz}, 1 \mathrm{H}), 8.27$ (s, $1 \mathrm{H}), 8.18(\mathrm{~d}, J=8.1 \mathrm{~Hz}, 1 \mathrm{H}), 7.95-7.88(\mathrm{~m}, 2 \mathrm{H}), 7.70(\mathrm{~m}, 1 \mathrm{H})$, $7.56(\mathrm{~m}, 1 \mathrm{H}), 7.48$ (d, $J=7.8 \mathrm{~Hz}, 1 \mathrm{H}), 7.45-7.39(\mathrm{~m}, 2 \mathrm{H}), 7.31(\mathrm{~s}$, $1 \mathrm{H}), 7.08(\mathrm{~d}, J=8.5 \mathrm{~Hz}, 1 \mathrm{H}), 7.00(\mathrm{~d}, J=8.4 \mathrm{~Hz}, 1 \mathrm{H}), 6.59(\mathrm{~d}, J=$ $3.1 \mathrm{~Hz}, 1 \mathrm{H}), 5.71$ (s, 2H), 2.98 (q, $J=7.5 \mathrm{~Hz}, 2 \mathrm{H}), 2.67$ (s, 3H), $1.35(\mathrm{t}, J=7.5 \mathrm{~Hz}, 3 \mathrm{H}) .{ }^{13} \mathrm{C}$ NMR (101 MHz, DMSO): $\delta \mathrm{ppm}$ 167.6 , 166.5, 159.4, 156.4, 146.7, 145.6, 143.2, 137.8, 136.5, $135.8,133.1,131.1,130.91,129.6,129.0,128.8,128.7,128.4$, $128.4,121.7,121.1,120.7,119.4,119.1,118.6,110.7,108.6$, 103.2, 47.0, 20.9, 16.9, 12.1. HRMS (ESI): $\mathrm{m} / \mathrm{z}$ calcd for $\mathrm{C}_{32} \mathrm{H}_{26} \mathrm{~N}_{5} \mathrm{O}_{3}[\mathrm{M}+\mathrm{H}]^{+}$: 528.2036; found 528.2038.

2-(5-((2-Propyl-4-methyl-6-(oxazolo[4,5-b]pyridine-2-yl)benzimidazole-1-yl)methyl)-1H-indol-1-yl)benzoic acid (2e). The synthesis of compound $2 \mathbf{e}$ was similar to that of compound 1a, obtaining as white solid. Yield: $45 \%$. Mp: $263-265{ }^{\circ} \mathrm{C} .{ }^{1} \mathrm{H}$ NMR (400 MHz, DMSO- $d_{6}$ ): $\delta$ ppm $12.91(\mathrm{~s}, 1 \mathrm{H}), 8.50(\mathrm{~d}, J=4.8 \mathrm{~Hz}$, $1 \mathrm{H}), 8.24(\mathrm{~s}, 1 \mathrm{H}), 8.17(\mathrm{~d}, J=8.1 \mathrm{~Hz}, 1 \mathrm{H}), 7.94(\mathrm{~s}, 1 \mathrm{H}), 7.86(\mathrm{~d}, J=$ $7.7 \mathrm{~Hz}, 1 \mathrm{H}), 7.66(\mathrm{~m}, 1 \mathrm{H}), 7.53(\mathrm{~m}, 1 \mathrm{H}), 7.47-7.38(\mathrm{~m}, 3 \mathrm{H}), 7.29$ $(\mathrm{s}, 1 \mathrm{H}), 7.10(\mathrm{~d}, J=8.5 \mathrm{~Hz}, 1 \mathrm{H}), 6.99(\mathrm{~d}, J=8.5 \mathrm{~Hz}, 1 \mathrm{H}), 6.57(\mathrm{~d}, J$ $=3.0 \mathrm{~Hz}, 1 \mathrm{H}), 5.72(\mathrm{~s}, 2 \mathrm{H}), 2.94(\mathrm{t}, J=7.6 \mathrm{~Hz}, 2 \mathrm{H}), 2.66(\mathrm{~s}, 3 \mathrm{H})$, 1.88-1.74 (m, 2H), $1.00(\mathrm{t}, J=7.3 \mathrm{~Hz}, 3 \mathrm{H}) .{ }^{13} \mathrm{C}$ NMR $(101 \mathrm{MHz}$, DMSO): $\delta$ ppm 167.4, 166.1, 157.9, 155.9, 146.3, 145.2, 142.7, $137.0,136.0,135.2$, 132.1, 130.5, 130.5, 129.1, 128.6, 128.6, 128.2 , 128.1, 127.8, 121.3, 120.5, 120.2, 119.0, 118.6, 118.0, 110.4, 108.2, 102.6, 46.6, 28.8, 20.5, 16.4, 13.9. HRMS (ESI): $\mathrm{m} / \mathrm{z}$ calcd for $\mathrm{C}_{33} \mathrm{H}_{28} \mathrm{~N}_{5} \mathrm{O}_{3}[\mathrm{M}+\mathrm{H}]^{+}$: 542.2192; found 542.2190.

2-(5-((2-Butyl-4-methyl-6-(oxazolo[4,5-b]pyridine-2-yl)benzimidazole-1-yl)methyl)-1H-indol-1-yl)benzoic acid (2f). The synthesis of compound $2 \mathbf{f}$ was similar to that of compound 1a, obtaining as white solid. Yield: $49 \%$. Mp: $264-266{ }^{\circ} \mathrm{C} .{ }^{1} \mathrm{H}$ NMR $(400 \mathrm{MHz}$, DMSO- $\left.d_{6}\right): \delta$ ppm $12.89(\mathrm{~s}, 1 \mathrm{H}), 8.51(\mathrm{~m}, 1 \mathrm{H}), 8.26(\mathrm{~s}, 1 \mathrm{H}), 8.18$ (m, 1H), $7.94(\mathrm{~s}, 1 \mathrm{H}), 7.87$ (d, $J=7.9 \mathrm{~Hz}, 1 \mathrm{H}), 7.67(\mathrm{~m}, 1 \mathrm{H})$, 
7.56-7.52 (m, 1H), 7.48-7.39 (m, 3H), 7.29 (s, 1H), $7.10(\mathrm{~m}, 1 \mathrm{H})$, $6.99(\mathrm{~d}, J=8.6 \mathrm{~Hz}, 1 \mathrm{H}), 6.57(\mathrm{~d}, J=3.2 \mathrm{~Hz}, 1 \mathrm{H}), 5.72(\mathrm{~s}, 2 \mathrm{H}), 2.96$ $(\mathrm{t}, 2 \mathrm{H}), 2.66(\mathrm{~s}, 3 \mathrm{H}), 1.88-1.71(\mathrm{~m}, 2 \mathrm{H}), 1.46-1.36(\mathrm{~m}, 2 \mathrm{H}), 0.90(\mathrm{t}$, $J=7.3 \mathrm{~Hz}, 3 \mathrm{H}) .{ }^{13} \mathrm{C}$ NMR (101 MHz, DMSO): $\delta \mathrm{ppm} \mathrm{167.3,} \mathrm{166.1,}$ $158.0,155.9,146.3,145.2,142.7,137.1,136.0,135.2,132.2$, $130.5,130.5$, 129.1, 128.6, 128.6, 128.2, 128.1, 127.8, 121.3, $120.5,120.2$, 118.9, 118.6, 118.0, 110.4, 108.2, 102.7, 46.6, 29.2, 26.7, 22.0, 16.4 13.7. HRMS (ESI): $m / z$ calcd for $\mathrm{C}_{34} \mathrm{H}_{30} \mathrm{~N}_{5} \mathrm{O}_{3}[\mathrm{M}+$ $\mathrm{H}]^{+}$: 556.2349; found 556.2349.

\section{Biological evaluation}

Affinities to Ang II ( $\left.\mathbf{A T}_{\mathbf{1}}\right)$ receptor in vitro. The vascular smooth muscle cells (VSMCs) were obtained from thoracic aorta of SD rats and cultured by the tissue explants methods, and cells at generation 3-7 were used for the experiments. The prepared compounds and losartan were dissolved in DMSO respectively and diluted to different concentrations from $1 \times 10^{-10} \mathrm{M}$ to $1 \times$ $10^{-4} \mathrm{M}$ with PBS before the experiments. [ $\left.{ }^{125} \mathrm{I}\right] \mathrm{Sar} 1$, Ile8angiotensin II (Shanghai First people's Hospital, Shanghai, China) was used in this assay. VSMCs $\left(10^{6}\right.$ cells per well, $\left.500 \mu \mathrm{L}\right)$ were seeded into 24 -well plates at $37{ }^{\circ} \mathrm{C}$ in $5 \% \mathrm{CO}_{2} .0 .1 \mathrm{nM}^{125} \mathrm{I}-$ Ang II and compounds of different concentrations were maintained in all samples when the cells adhered to the wall. Then they were cultivated at $4{ }^{\circ} \mathrm{C}$ for $150 \mathrm{~min} .^{16,17}$ Nonspecific binding was measured in the presence of $1 \mu \mathrm{M}$ Ang II. Cells bound by ${ }^{125}$ I-Ang II were counted by $\gamma$-counter (SN-682, Rihuan Company, Shanghai). The $\mathrm{IC}_{50}$ value was estimated by the linear portion of the competition curves.

Antihypertensive activities in vivo. 162 male spontaneous hypertensive rats (SHRs) $(250 \pm 20 \mathrm{~g}$, Beijing Vital River Laboratory Animal Co., Ltd Beijing, China) were used to evaluate the effects on systolic blood pressure (SBP) and diastolic blood pressure (DBP) of new compounds. SHRs were randomly divided into 27 experimental groups: negative control group, losartan ( $5 \mathrm{mg} \mathrm{kg}^{-1}, 10 \mathrm{mg} \mathrm{kg}^{-1}$ ) groups and compound $\mathbf{1 a - f}$, 2a-f (5 mg kg $\left.{ }^{-1}, 10 \mathrm{mg} \mathrm{kg} \mathrm{kg}^{-1}\right)$ groups. Losartan and new compounds were suspended in a $0.5 \%$ solution of sodium carboxymethyl cellulose and administered orally. SHRs in negative control group were administered with the same volume of sodium carboxymethyl cellulose solution. Systolic blood pressure (SBP), diastolic blood pressure (DBP) and heart rates (HR) were monitored pre-dose and after dose by a biological signal analysis system (MPA-2000, Alcott Biotech, China). Six determinations were made in every session of blood pressure measurements and the means of the six values were taken as the SBP level and DBP level, respectively. The mean arterial pressure $(\mathrm{MBP})$ was calculated by the formula: $\mathrm{MBP}=(\mathrm{SBP}-\mathrm{DBP}) / 3+$ $\mathrm{DBP}$, and all the results were expressed as mean \pm SD. A probability level of less than 0.05 was considered significant.

Pharmacokinetic characteristics of compound 1f. Liquid chromatography-mass spectrometry (LC-MS) method was used to analyze the drug concentration of compound $1 \mathrm{f}$ in plasma and in tissues. Agilent LC-MS electrospray ionization (ESI) single quadrupole mass spectrometer using a C18 column 2.1 $\mathrm{mm} \times 150 \mathrm{~mm}, 3 \mu \mathrm{m}$ with following mobile phases: (A) $\mathrm{H}_{2} \mathrm{O}$ $0.1 \%$ formic acid and (B) acetonitrile. The flow rate was $0.2 \mathrm{~mL}$ $\min ^{-1}$ and the injection volume was $20 \mu \mathrm{L}$. The Gradient elution program of mobile phase A : B (v/v) were $55: 45$ (1-10 min), 30 : 70 (10-11 $\mathrm{min}), 55: 45$ (11-18 $\mathrm{min})$. LC-MS spectral data of each single sample were collected, Microsoft Excel program, Origin 8.0 and DAS 2.0 software were used to calculate the pharmacokinetic parameters.

8 male Wistar rats (180-200 g, Shanghai Slac Laboratory Animal Company, Shanghai, China) were used and administrated with 1 f at dose of $10 \mathrm{mg} \mathrm{kg}^{-1}$. Blood samples were collected from each rat by retro-orbital puncture at a predetermined time interval of pre-dose, 0.5, 1, 2, 4, 6, 8, 12, 24, 48 and $72 \mathrm{~h}$ into the polypropylene microfuge tubes containing heparin. Plasma was separated by centrifuging the blood samples at $4000 \times g$ at $4{ }^{\circ} \mathrm{C}$ for $10 \mathrm{~min}$. $200 \mu \mathrm{L}$ plasma samples were collected and followed by $100 \mu \mathrm{L}$ of internal standard. Acetonitrile $(200 \mu \mathrm{L})$ was added to precipitate proteins and the sample was vortexed for $1 \mathrm{~min}$. Precipitated proteins were separated by centrifugation for $5 \mathrm{~min}$ at $12000 \times g$ at $4{ }^{\circ} \mathrm{C}$. The supernatant was filtered by needle filter of $0.22 \mu \mathrm{m}$ and the resulting $20 \mu \mathrm{L}$ filtrate was taken to analyze in LC-MS. Linearity for $\mathbf{1 f}$ was tested by extracting plasma standards spiked at nominal concentrations of $0.2,0.5,1.0,2.0,5.0,10.0,100.0 \mu \mathrm{g} \mathrm{mL}{ }^{-1}$. The calibration line was generated by least squares linear regression of the peak height ratio (PHR) of analyte/internal standard against nominal concentration with a weighting of concentration ${ }^{-2} \cdot \cdot^{18,19}$

66 male Wistar rats (180-200 g, Shanghai Slac Laboratory Animal Company, Shanghai, China) were used to investigate the tissue distribution of compound 1f. Animals were orally administrated with $\mathbf{1 f}$ at $10 \mathrm{mg} \mathrm{kg}^{-1}$. Heart, liver, spleen, lung, kidney and brain samples were collected at 0 (prior to dosing), $0.5,1,2,4,6,8,12,24,48$ and $72 \mathrm{~h}$ post-dosing $(n=6) .0 .25 \mathrm{~g}$ samples from different tissues were obtained after being rinsed with normal saline solution and blotted with filter paper. The samples were grinded into tissue fluid $(0.25 \mathrm{~g} / 1 \mathrm{~mL}$ normal saline solution) with High-speed Homogenizer (PRO200, Biogen series, USA). The tissue fluid was added with $4 \mathrm{~mL}$ methanol and vortexed for $1 \mathrm{~min}$ and then centrifuged at $10000 \times g$ for $10 \mathrm{~min} .2 \mathrm{~mL}$ supernatant was obtained and dried in gentle stream of nitrogen flow at $50{ }^{\circ} \mathrm{C}$. The residue was spun for $2 \mathrm{~min}$ after being reconstituted with $100 \mu \mathrm{L}$ methanol, and was centrifuged at $12000 \times g$ for 5 min to get supernatant sample. $20 \mu \mathrm{L}$ supernatant samples were taken to analyze through LC-MS. ${ }^{17}$

Acute toxicity test. To detect the safety of compound 1f, the acute toxicity assay was carried out with 50 normal ICRs (18-20 g, Academia Sinica, China). The $\mathrm{LD}_{50}$ value was delivered via intragastric administration (ig) at doses of 3331.94, 2332.36, $1632.65,1142.86,800.00 \mathrm{mg} \mathrm{kg}{ }^{-1}$. The lethal dose $\left(\mathrm{LD}_{50}\right)$ and 95\% confidence limits were determined by logistic regression analysis (GLM) curve fitting of the 14 days' mortality data. Survivals were observed continuously and recorded systematically for physiological toxicity including weight, mobility, aggressiveness and respiratory movements. At the 15 th day, the survivals were dissected to examine the pathological changes of organs. ${ }^{20}$

Statistics. Results were expressed as means \pm SD. Data were analyzed by one-way analysis of variance. When overall 
statistical significance was achieved $(P<0.05)$, anova one way and $t$-test statistical were used to compare each of the doses to the vehicle control. Probability values less than 0.05 were considered to be significant. Binding isotherms from competition studies were obtained using the nonlinear regression program GraphPad Prism 5 software (Network of Science Software of China) and pharmacokinetic parameters were acquired by DAS.2.0 software. Animals were maintained in accordance with the guidelines issued by the Institutional Animal Care and Use Committee of China, and approved by the institutional ethical committee of Donghua University.

\section{Acknowledgements}

This work was supported by Science and Technology Commission of Shanghai Municipality (Grant No. 14431906200, 15XD1523400, 15ZR1439900), National Natural Science Foundation of China (No. 21372042), and the Fundamental Research Funds for the Central Universities (Grant No. CUSF-DH-D2016041).

\section{References}

1 J. L. Wang, J. Zhang, M. Zhou, Z. H. Li, W. Z. Xue, D. Xu, L. P. Hao, X. F. Han, F. Fei, T. Liu and A. H. Liang, Eur. J. Med. Chem., 2012, 49, 183-190.

2 A. Bali, Y. Baansal, M. Sugumaran, J. S. Saggu, P. Balakumar, G. Kaur, G. Bansal, A. Sharma and M. Singh, Bioorg. Med. Chem. Lett., 2005, 15, 3962-3966.

3 G. Bakris, A. Gradman, M. Reif, M. Wofford, M. Munger, S. Harris, J. Vendetti, E. L. Michelson and R. Wang, J. Clin. Hypertens., 2001, 3, 16-31.

4 J. A. Brousil and J. M. Burke, Clin. Ther., 2003, 25, 1041-1055. 5 J. Zhang, J. L. Wang, W. F. Yu, Z. M. Zhou, W. C. Tao, Y. C. Wang, W. Z. Xue, D. Xu, L. P. Hao, X. F. Han, F. Fei, T. Liu and A. H. Liang, Eur. J. Med. Chem., 2013, 69, 44-54. 6 K. S. Kumar, B. Rajesham, M. S. Ramulu, B. Bhaskar, S. N. Dash, M. A. Ashfaq, R. Nagarapu, A. A. Khan, S. Lehtonen and M. Pal, RSC Adv., 2016, 6, 100487-100493.
7 U. Herzberg, E. Eliav, G. J. Bennett and I. J. Kopin, Neurosci. Lett., 1997, 221, 157-160.

8 U. Jacquemard, N. Dias, A. Lansiaux, C. Bailly, C. Logé, J. M. Robert, O. Lozach, L. Meijer, J. Y. Mérour and S. Routier, Bioorg. Med. Chem., 2008, 16, 4832-4953.

9 N. Sharaf El-Dina and A. Barseem, J. Pharm. Sci., 2016, 6, 075-083.

10 X. L. Bao, W. B. Zhu, H. Ren, Y. J. Da, D. Wu, F. M. Li, Y. J. Yan, L. Wang and Z. L. Chen, Eur. J. Med. Chem., 2016, 115, 167-178.

11 W. Wienen, M. Entzeroth, J. C. A. Meel, J. Stangier, U. Busch, T. Ebner, J. Schmid, H. Lehmann, K. Matzek, J. KempthorneRawsonK, V. Gladigau and N. H. Hauel, Cardiovasc. Drug Rev., 2000, 18, 127-154.

12 G. Berellini, G. Cruciani and R. Mannhold, J. Med. Chem., 2005, 48, 4389-4399.

13 A. Justin, M. Sathishkumar, A. Sudheer, S. Shanthakumari and M. Ramanathan, Pharmacol., Biochem. Behav., 2014, 122, 61-73.

14 T. Haraguchi, K. Iwasaki, K. Takasaki, K. Uchida, T. Naito, A. Nogami, K. Kubota, T. Shindo, N. Uchida, S. Katsurabayashi, K. Mishima, R. Nishimura and M. Fujiwara, Brain Res., 2010, 1353, 125-132.

15 C. M. Qi, L. C. Yang, G. X. Zhang and H. Yu, China Pat., CN1623992A, 2005.

16 X. L. Bao, W. B. Zhu, H. Ren, P. Y. Liao, W. Zhu, Y. J. Yan, L. Wang and Z. L. Chen, Clin. Exp. Hypertens., 2016, 38, 435-442.

17 W. B. Zhu, X. L. Bao, R. J. Zhang, C. H. Wen, L. Wang, Y. J. Yan, H. S. Tang and Z. L. Chen, Eur. J. Med. Chem., 2016, 123, 115-127.

18 G. Y. Cao, P. Y. Ying, B. Yan, W. Xue, K. X. Li, A. X. Shi, T. H. Sun, J. L. Yan and X. Hua, J. Ethnopharmacol., 2015, 168, 31-36.

19 K. W. Mosure, J. O. Knipe, M. Browning, V. Arora, Y. Z. Shu, T. Phillip, F. Mcphee, P. Scola, A. Balakrishnan, M. G. Soars, K. Santone and M. Sinz, J. Pharm. Sci., 2015, 104, 2813-2823.

20 Y. J. Da, T. Xin, Y. Y. Nie, Y. Ye, Y. J. Yan, L. S. Liang and Z. L. Chen, Bioorg. Med. Chem., 2012, 20, 7101-7111. 